Article

\title{
Insights onto Hydrologic and Hydro-Chemical Processes of Riparian Groundwater Using Environmental Tracers in the Highly Disturbed Shaying River Basin, China
}

\author{
Baoling Li ${ }^{1,2,3}$, Xianfang Song ${ }^{1,2, *}$, Lihu Yang ${ }^{1,2, *}$, Dongxu Yao ${ }^{1,2}$ and Yingchun $\mathrm{Xu}^{1,2}$ \\ 1 Key Laboratory of Water Cycle and Related Land Surface Processes, Institute of Geographic Sciences and \\ Natural Resources Research, Chinese Academy of Sciences, Beijing 100101, China; \\ libaoling15@mails.ucas.ac.cn (B.L.); yaodongxu16@mails.ucas.edu.cn (D.Y.); 16619724903@163.com (Y.X.) \\ 2 University of Chinese Academy of Sciences, Beijing 100049, China \\ 3 Department of Plant and Environmental Sciences, University of Copenhagen, 1871 Copenhagen, Denmark \\ * Correspondence: songxf@igsnrr.ac.cn (X.S.); yanglihu@igsnrr.ac.cn (L.Y.); \\ Tel.: +86-010-6488-9849 (X.S.); +86-010-6488-8266 (L.Y.)
}

Received: 9 June 2020; Accepted: 6 July 2020; Published: 8 July 2020

check for updates

\begin{abstract}
Understanding the hydrologic and hydrochemistry processes in the riparian area is of great importance for managing and protecting riparian water resources. This paper took a highly disturbed and polluted Shaying River Basin (SRB) of China as the study area. In this research, environmental tracers (hydrochemical and isotopic data of ${ }^{222} \mathrm{Rn}, \delta^{18} \mathrm{O}$, and $\delta \mathrm{D}$ ) and corresponding models (two-component mixing model and ${ }^{222} \mathrm{Rn}$ mass balance model) were employed to investigate the hydrologic and associated hydro-chemical process of riparian groundwater. The results indicated that rivers received groundwater discharge located at Xihua (J8), Zhoukou (Y1), Luohe (S2), and Shenqiu (SY2), and the mixing extent with groundwater was greater in wet seasons than in dry seasons. The ${ }^{222} \mathrm{Rn}$ mass balance model showed that the flux of river water leakage was $3.27 \times 10^{-4} \mathrm{~m}^{3} /(\mathrm{s} \cdot \mathrm{m})$ at the front of Zhoukou sluice while groundwater discharge was $3.50 \times 10^{-3} \mathrm{~m}^{3} /(\mathrm{s} \cdot \mathrm{m})$ at the front of Shenqiu sluice during the sampling period. The cation exchange and the dissolution/precipitation of aquifer minerals (including calcite, dolomite, gypsum, and halite) were dominated by geochemical processes. The untreated sewage discharge and fertilizer usage were the main anthropogenic activities affecting the hydrochemistry process in surface water and riparian groundwater. Additionally, our results found that nitrate pollutants derived by riparian groundwater were potential threats to river quality at the lower reaches of Jialu River and Shenqiu county of Shaying River, where the nitrate inputs could be larger during the wet seasons because of higher groundwater discharge.
\end{abstract}

Keywords: hydrochemistry; environmental tracers; radon; riparian groundwater; Shaying River

\section{Introduction}

Riparian zones are defined as transition areas between terrestrial and aquatic ecosystems and are important for residents and for the industrial and agriculture sector. Surface water and groundwater in riparian zones are not completely independent but are interconnected components of the river basin system [1]. Various hydrologic and hydro-chemical $(\mathrm{H}-\mathrm{H})$ processes could take place simultaneously between the mixing of the two water bodies. Water quality and quantity in riparian zones are controlled not only by the hydrogeological settings but also by the human activities in the watershed. Over the past few decades, the increase of anthropogenic activities, including population growth, 
rapid urbanization, intensive agriculture, and industrial activities have greatly threatened the quality in surface water and riparian groundwater mainly due to increased nitrogen pollution $[2,3]$. Elevated nitrate concentration in water bodies has not only caused severe harm to ecosystems (eutrophication and toxic algal blooms), but also threaten residents' health (methemoglobinemia and stomach cancer) $[4,5]$. Due to its stability, high solubility, and mobility [6], nitrate in surface water can be easily transferred to the connected riparian groundwater, which causes groundwater pollution and vice versa. Thus, the investigation of the hydrologic and hydro-chemical processes of riparian groundwater is vitally essential for identifying nitrate pollutants pathways and for providing a scientific management strategy for mitigating nitrogen pollution.

Environmental tracers are physical properties and chemical components of water including water temperature, $\mathrm{pH}$, electrical conductivity, chloride and other ions, stable isotopes, and radioisotopes [7]. The spatial and temporal differentiation of environmental tracers could infer information on the pathways and dynamics of water and solutes movement through the environment [8-13]. The hydrochemistry has been found to change along the flow path due to water-rock interactions and the mixing process with other water bodies. Radon $\left({ }^{222} \mathrm{Rn}, \mathrm{t}_{1 / 2}=3.84\right.$ days $)$ is a naturally radioactive noble gas generated by radioactive decay of radium ${ }^{226} \mathrm{Ra}$. The primary reservoir of radioactive radium ${ }^{226} \mathrm{Ra}$ is below-ground sedimentary rocks. Therefore, dissolved radon generally has a low activity in surface water in that the solubility of ${ }^{222} \mathrm{Ra}$ is low. Once groundwater flow into a river, the ${ }^{222} \mathrm{Rn}$ is also released into it and declined downstream due to radioactive decay and atmospheric losses. Previous research indicated that the radon activity in groundwater is often at least 2 3 orders of magnitude higher than in surface waters [14]. Therefore, ${ }^{222} \mathrm{Rn}$ has been commonly used to evaluate the mixing process and quantify exchange flux between surface water and riparian groundwater $[8,11]$. Another isotope, ${ }^{18} \mathrm{O}$ and ${ }^{2} \mathrm{H}$, could only be altered by physical processes such as diffusion, mixing, and evaporation under normal temperatures instead of a chemical reaction $[15,16]$. Hence, they were also regarded as ideal natural tracers for understanding hydro-chemical evolution and mixing process between the river and riparian groundwater. A combination of multi-environment tracers could considerably reduce the individual tracer uncertainties and it has been strong and highly recommended for insight into the hydrologic and hydro-chemical processes in recent studies [17-19].

The Huai River, located in Eastern China, is the third-longest river in China. In the last few decades, urban, industrial, and agricultural activities have released a massive amount of organic and nitrogen pollutants into the aquatic environment. As the largest sub-basin in the Huai River, the SRB is a typical area with river and groundwater pollution, especially in terms of nitrogen pollution [20-24]. In order to control the flooding and relieve the water shortages, a large amount of water conservancy projects (e.g., dams and sluices) have been built [25] and were usually opened during wet seasons and closed during dry seasons. The river stage and streamflow were altered seasonally by the joint regulation of multiple dams and sluices, which led to considerable changes in the riparian hydrologic and hydrochemistry processes (e.g., the patterns of groundwater and surface water (GW-SW) exchange and nitrogen pathways). As a linear source of groundwater contamination, the nitrogen polluted river has dramatically threatened the riparian groundwater quality [26-28]. Meanwhile, polluted groundwater discharge was also one of the dominant sources of river nitrogen pollution [29]. Recently, there is more research about nitrogen concentration, GW-SW interactions, and the impact of anthropogenic and natural factors on surface water quality [22,25,30-34]. However, few studies have focused on the hydrologic processes between riparian groundwater and river during various hydrological periods. Processes controlling river and riparian groundwater chemistry were also ignored in previous studies. To develop effective strategies for mitigating nitrogen pollution and to achieve the sustainability of water resources in a connected fluvial and aquifer system, it is greatly important to correctly understand the hydrologic and hydro-chemical processes in riparian groundwater.

This paper aims to define the hydrologic and hydro-chemical process of riparian groundwater located in the highly disturbed SRB, China. Based on the field investigation carried out during dry and wet seasons, the objectives are to integrate multi-environmental tracers (hydro-chemical parameters, 
isotopes deuterium, oxygen-18 and ${ }^{222} \mathrm{Rn}$ ) to (i) identify locations where the river loses zones and gains zones, (ii) estimate mixing processes and quantify exchange fluxes between riparian groundwater and surface water, and (iii) determine the dominant geochemical processes and nitrate sources responsible for groundwater and surface water quality.

\section{Study Area}

As the largest sub-basin in Huai River Basin, China, the SRB is located between longitudes $112^{\circ} 45^{\prime}$ and $113^{\circ} 15^{\prime} \mathrm{E}$ and latitudes $32^{\circ} 20^{\prime}$ and $34^{\circ} 34^{\prime} \mathrm{N}$. The river has a length of $626 \mathrm{~km}$ and the watershed occupies a total area of approximately $39,880 \mathrm{~km}^{2}$ (Figure 1). It originates from Xinmi county in Henan province and is flowing through Zhengzhou city, Zhoukou city, Fuyang city, and then down into the Huai River mainstream near Mohekou in the Anhui Province. The main river is composed of the Jialu River, the Ying River, and the Sha River, which converge in Shaying River (at Zhoukou city in Henan province). The upstream is between the source and the Zhoukou hydrological station, while the midstream region is between the Zhoukou hydrological station and the Fuyang hydrological station. About $50 \mathrm{~km}$ downstream of the confluence, Huaidian sluice was built as one of the most important floodgates in the river in the 1970s. The terrain slopes from northwest to southeast [35]. The western part of the study area is mainly mountainous and hilly, whose altitude above mean sea level (amsl) varies greatly (around 600-1500 m). The east part is mostly plain (about 30-100 m amsl). Land use in SRB is classified into four major land types: urban, farmland, forest, and open water (Figure 2a). It is mostly agricultural land, which accounts for $61.92 \%$ of its land coverage (data of 2018, obtained from the Resources and Environmental Sciences Data Center, Chinese Academy of Sciences RESDC. Available online: http://www.resdc.cn/data.aspx (accessed on 1 May 2020).

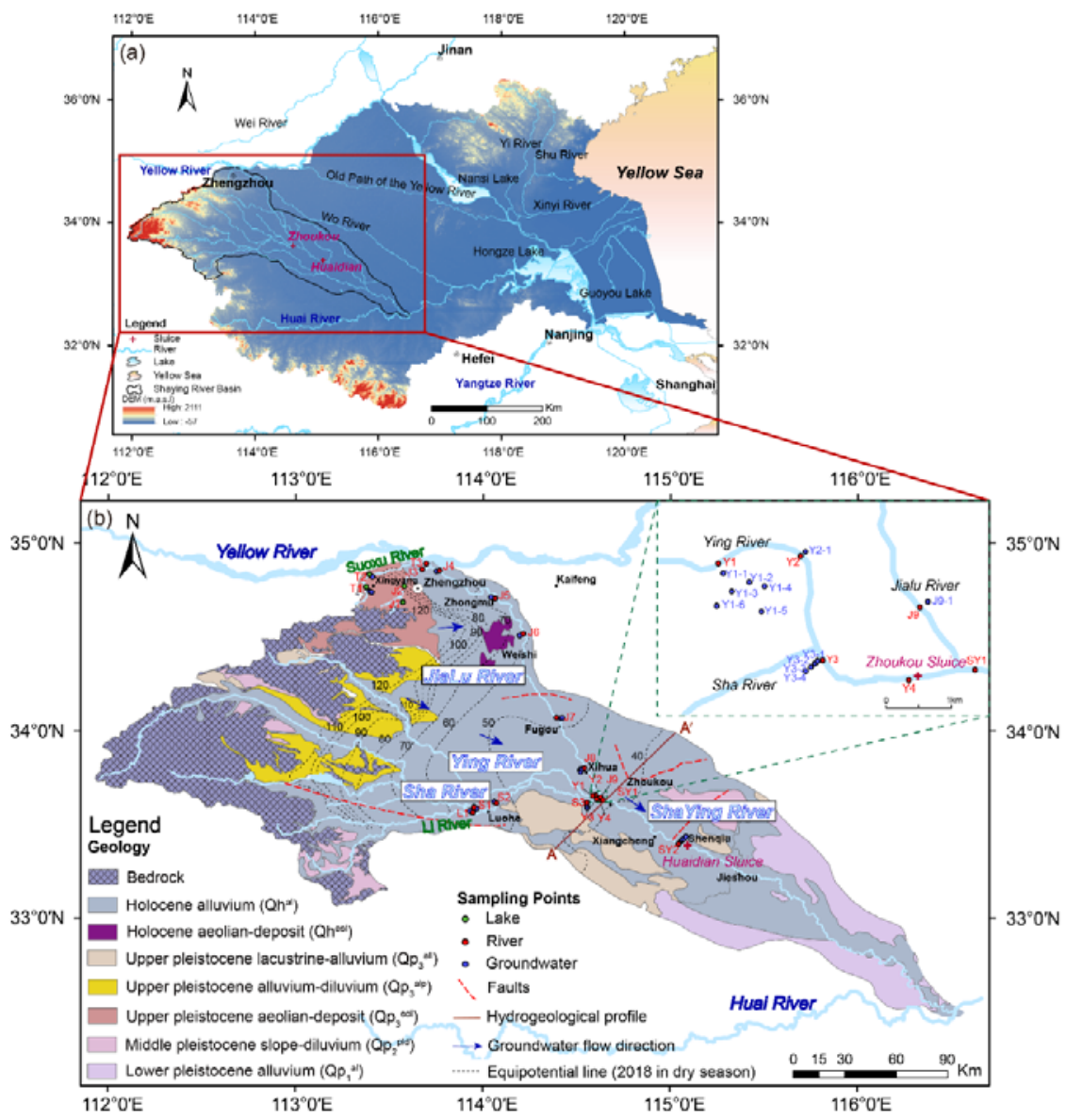

Figure 1. The location, topography map, sampling sites, and hydrogeological map of the study area. (a) Shows the location and topography of the study area. (b) Hydrogeological map and sampling sites distribution. 


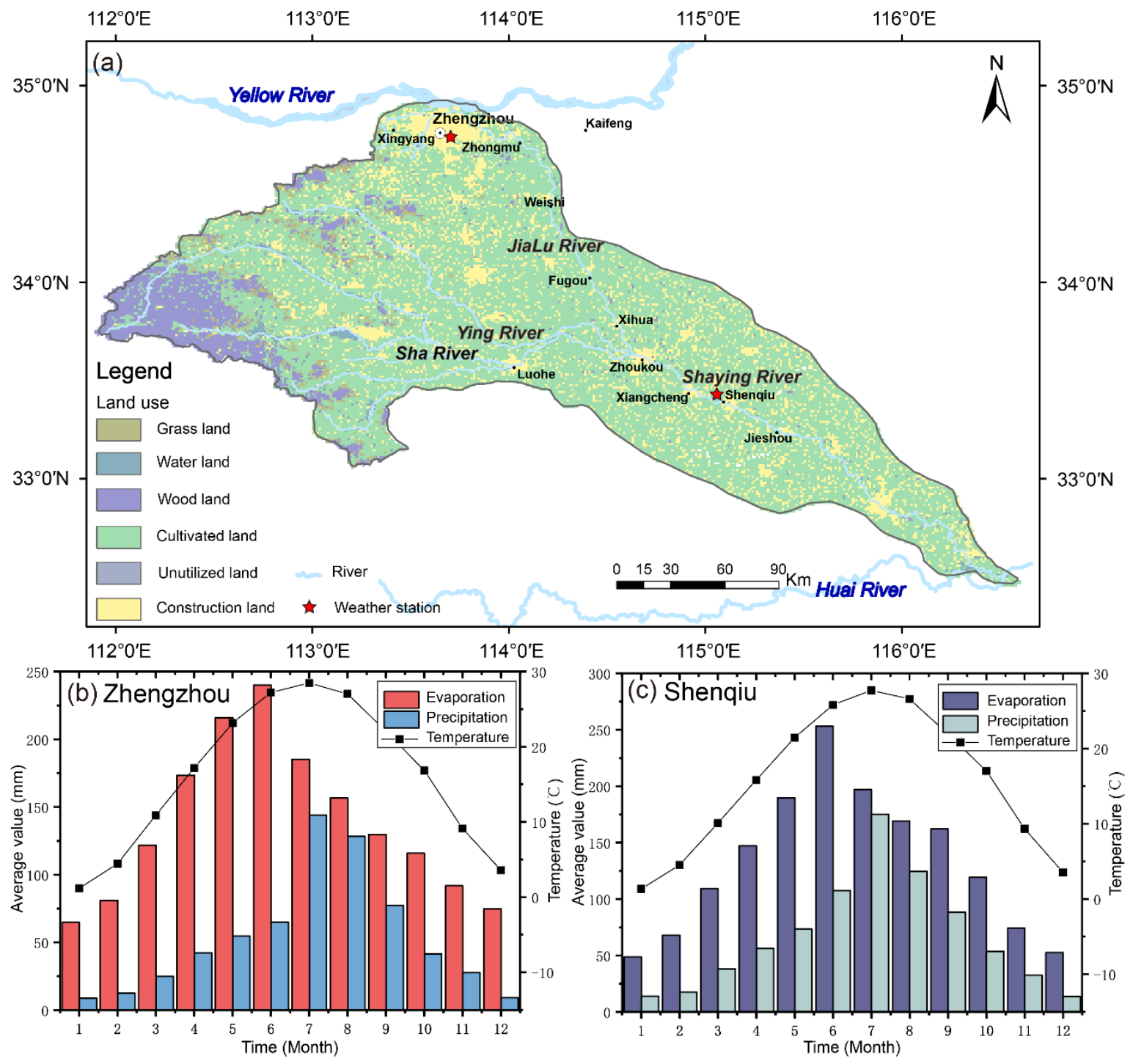

Figure 2. The land use and the meteorological data in the study area. (a) The land use in 2018 and weather station locations. The mean monthly variations of temperature, evaporation, and precipitation at (b) Zhengzhou weather station (1951-2018) and (c) Shenqiu weather station (1957-2018).

SRB belongs to the continental monsoon climate, and there is a difference in precipitation between the mountainous region and the plain region, which shows the northwest as less (623-807 mm/year) and more in the southeast (807-970 mm/year) [36]. According to meteorological data (between 1951-2018) from the Zhengzhou weather station (Figure $2 \mathrm{~b}$ ), the average annual temperature varies from $14{ }^{\circ} \mathrm{C}$ to $17^{\circ} \mathrm{C}$ while mean potential evaporation is around $1651.3 \mathrm{~mm}$. The annual rainfall is $636.6 \mathrm{~mm}$ and the variation of annual rainfall is at a maximum value of $1040.7 \mathrm{~mm}$ in 1964 to a minimum value of $353.2 \mathrm{~mm}$ in 2013. The atmospheric precipitation accounts for about $65 \%$ of yearly rainfall from June to September. According to meteorological data from 1957 to 2018 from the Shenqiu weather station (Figure 2c), the average monthly temperature ranges from $13^{\circ} \mathrm{C}$ to $17^{\circ} \mathrm{C}$. The mean annual potential evaporation is $1591.1 \mathrm{~mm}$. The average annual precipitation is $794.6 \mathrm{~mm}$, and the rainfall from June to September accounted for about $62 \%$ of the annual precipitation.

Outcropping strata are mainly bedrock of granite and granodiorite in the western mountainous area, and Quaternary $(\mathrm{Q})$, including Holocene alluvium $\left(\mathrm{Qh}^{\mathrm{al}}\right)$, Holocene aeolian-deposit $\left(\mathrm{Qh}^{\mathrm{eol}}\right)$, Upper Pleistocene lacustrine-alluvium ( $\left.\mathrm{Qp}_{3}{ }^{\text {all }}\right)$, Upper Pleistocene alluvium-diluvium $\left(\mathrm{Qp}_{3}{ }^{\text {alp }}\right)$, Upper Pleistocene aeolian-deposit $\left(\mathrm{Qp}_{3}{ }^{\mathrm{eol}}\right)$, Middle Pleistocene slope-diluvium $\left(\mathrm{QP}_{2}{ }^{\mathrm{pld}}\right)$, and Lower 
Pleistocene alluvium $\left(\mathrm{QP}_{1}{ }^{\mathrm{al}}\right)$ are found from the piedmont area to the plain area. The tectonic structures of the study area developed several normal faults in northeast and northwest directions. The groundwater flows predominantly from the northwest to the southeast which flows from west to east in the south and west part of SRB. In consideration of stratigraphic structure, burial conditions, and hydrodynamic characteristics, the aquifer is divided into the shallow aquifer $(<50 \mathrm{~m})$ and deep aquifer $(>50 \mathrm{~m})$ in the SRB [37]. The shallow aquifer mainly consists of silty sand, fine sand, silt, and silty clay. It got recharged mainly from atmospheric precipitation, which is followed by river seepage, channel infiltration, mountainous lateral runoff, and irrigation return flows and discharge through evaporation, drainage to rivers, and human pumping. The deep aquifer is mainly made up of silt, silty clay, clay, silty sand, fine sand, and medium sand. The main recharge sources of the deep aquifer include lateral runoff and shallow groundwater overflow. The discharge is mainly through artificial exploitation (Figure 3).

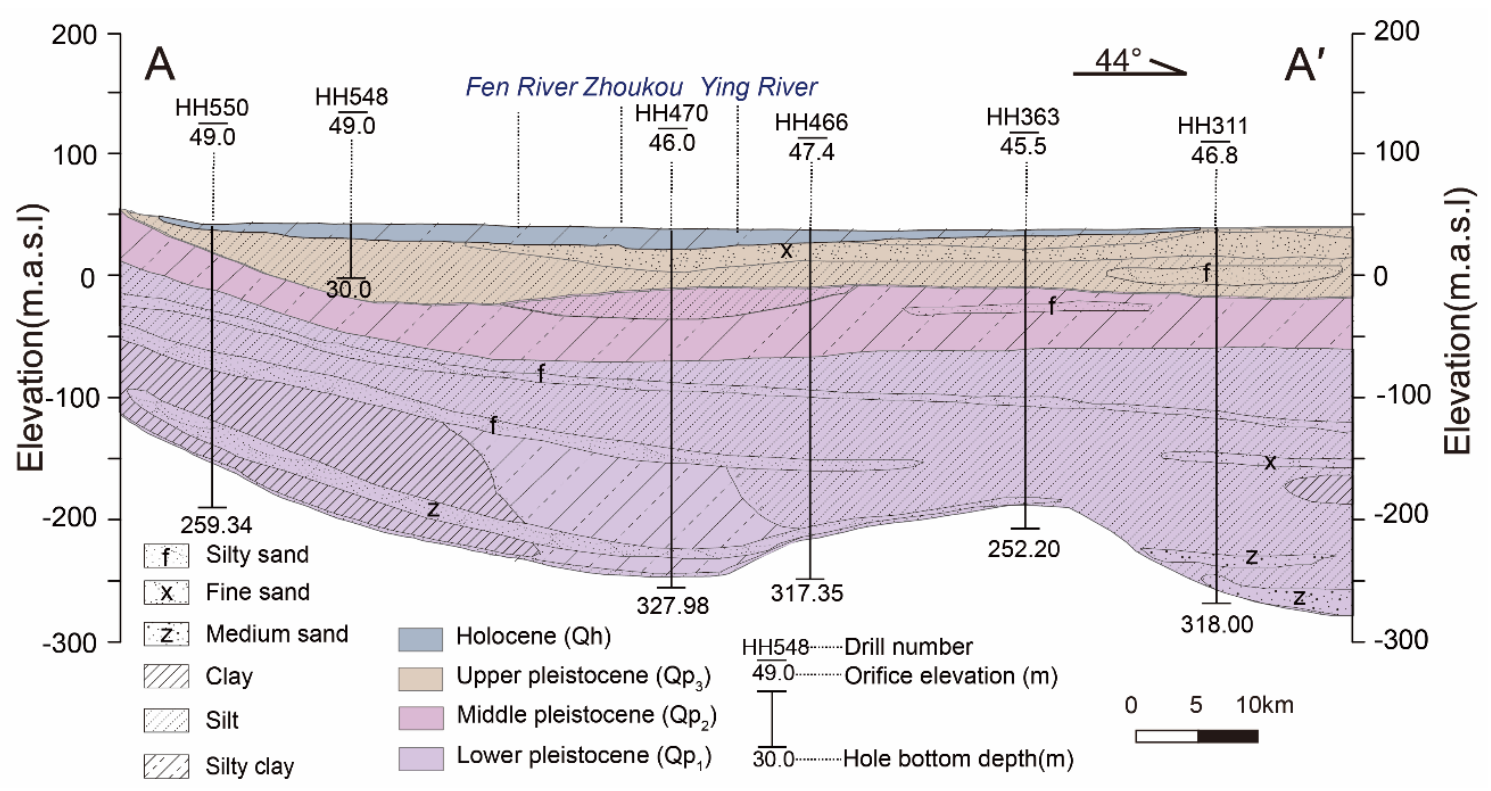

Figure 3. Hydrogeological cross section $\left(\mathrm{A}-\mathrm{A}^{\prime}\right)$ of the Shaying River Basin.

\section{Materials and Methods}

\subsection{Field Sampling and Sample Preparetion}

Samples of surface water and riparian groundwater (within $2 \mathrm{~km}$ from the river) were collected along the mainstream of the Shaying River and its major tributaries Jialu River, Shahe River, and Yinghe River during two sampling campaigns. The field investigations were mainly concentrated on the severely contaminated Jialu River and Shaying River (between Zhoukou sluice and Shenqiu sluice). The first campaign was conducted from 15 to 21 April 2019 during the dry season, including 31 groundwater samples, 16 river water, and 3 lake samples. The second campaign was conducted from 7 to 13 August 2019 during the wet season including 30 groundwater, 17 river water, and 4 lake samples. The sampling sites are shown in Figure 1. Y3 was around $2 \mathrm{~km}$ at the front of Zhoukou Sluice, while SY 2 was around $3 \mathrm{~km}$ at the front of Huaidian Sluice. River and lake samples were collected using an acrylic water sampler at a depth of around 10-15 cm below the surface of water. Riparian groundwater samples were selected from the existing village-supply wells with the depth about 6-50 $\mathrm{m}$ in the Quaternary aquifer, which took at least five times the volume of stagnant water in the well pumped out.

The water samples for hydro-chemical analysis were filtered in the field using 0.45 - $\mu \mathrm{m}$ cellulose acetate filter membrane and stored in the 100-mL polyethylene bottles. Samples for total nitrogen (TN) and chemical oxygen demand (CODcr) were acidified to $\mathrm{pH}<2$ by sulfuric acid $\left(20 \% \mathrm{H}_{2} \mathrm{SO}_{4}\right)$ in situ 
and sealed in 100-mL brown glass bottles, and then stored to avoid light. Samples for $\delta^{18} \mathrm{O}$ and $\delta^{2} \mathrm{H}$ measurements were collected in 50-mL glass bottles using gas-tight caps. Samples for ${ }^{222} \mathrm{Rn}$ were stored in 100-mL brown glass bottles. All samples were pre-rinsed with sample water three times before the final water sample was acquired and sealed with adhesive tape until analysis. Details of sampling data and other sampling descriptions were provided in Supplementary Materials Tables S1 and S2.

\subsection{In-Situ Measurements and Lab Analysis}

Water temperature, $\mathrm{pH}$, dissolved oxygen (DO), and electrical conductivity (EC) oxidation-reduction potential (ORP) were measured by portable multi-parameter devices (Hach HQ40d, Hanna combo, Hach company, Ames, IA, USA) in situ at the time of sample collection. The field water quality parameters were monitored until these values were stabilized. The water quality was measured at the Center for Physical and Chemical Analysis of Institute of Geographic Sciences and Natural Resources Research, Chinese Academy of Sciences (IGSNRR, CAS). The hydro-chemical compositions were analyzed for cations $\left(\mathrm{Na}^{+}, \mathrm{K}^{+}, \mathrm{Mg}^{2+}, \mathrm{Ca}^{2+}\right.$, and $\left.\mathrm{Sr}^{2+}\right)$ by an inductively coupled plasma optical emission spectrometer (ICP-OES, Perkin-Elmer Optima 5300DV, Waltham, MA, USA) and for anions $\left(\mathrm{F}^{-}, \mathrm{Cl}^{-}, \mathrm{SO}_{4}{ }^{2-}\right.$, and $\left.\mathrm{NO}_{3}{ }^{-}\right)$by an ion chromatography system (ICS-3000, Dionex, Waltham, MA, USA). The alkalinity $\left(\mathrm{HCO}_{3}{ }^{-}\right.$and $\mathrm{CO}_{3}{ }^{2-}$ ) of water samples was determined by titration with $\mathrm{H}_{2} \mathrm{SO}_{4}(0.22 \mathrm{~N})$ on the day of sample collection, phenolphthalein, and methyl orange as an indicator. The errors of charge balance were evaluated for the reliability of major cations and anions data. The calculated results of the charge balance errors showed that the deviation between the sum of concentrations of cations and anions was less than $\pm 10 \%$, which can be accepted in this study. Dissolved oxygen carbon (DOC) was measured by Elementar liquid TOC, Germany. The concentration level of chemical oxygen demand (CODcr) was determined using DR/5000 UV-vis HACH spectrophotometer (Hach company, Ames, IA, USA), by Reactor Digestion Method of Test $\mathrm{N}$ Tube vials ${ }^{\mathrm{TM}}$ (Method 8000). Detection limits were $3 \mathrm{mg} / \mathrm{L}$ for CODcr. Inorganic nitrogen concentration $\left(\mathrm{NO}_{2}-\mathrm{N}\right.$ and $\left.\mathrm{NH}_{3}-\mathrm{N}\right)$ was measured using a Hach DR/890 colorimeter in situ (Diazotization Method 8507 and Salicylate Method 8155 and 10031, respectively). Total nitrogen (TN) was quantified, according to the alkaline potassium persulfate digestion UV spectrophotometry method (HJ 636-2012), by Bran Luebbe AutoAnalyzer 3 , German. The difference between TN and dissolved inorganic nitrogen (DIN) (the sum of $\mathrm{NO}_{2}-\mathrm{N}$, $\mathrm{NH}_{3}-\mathrm{N}$, and $\mathrm{NO}_{3}-\mathrm{N}$ ) was used to determine dissolved organic nitrogen (DON).

Stable isotopes $\left({ }^{18} \mathrm{O}\right.$ and ${ }^{2} \mathrm{H}$ or $\left.\mathrm{D}\right)$ of the water samples were measured with a laser spectrometry DLT-100 Liquid-Water isotope analyzer, which is an automated injection designed by Los Gatos Research (LGR-DLT100, San Jose, CA, USA). Results were expressed relative to the international standards (V-SMOW for ${ }^{18} \mathrm{O}$ and ${ }^{2} \mathrm{H}$ ) expressed as a percentage. Each sample was tested at least six times and the reported value was the mean of six consistent results. The analytical uncertainties were $\pm 0.1 \%$ o $\delta^{18} \mathrm{O}$ and $\pm 1 \%$ o $\delta^{2} \mathrm{H}$. The analysis of ${ }^{222} \mathrm{Rn}$ was performed using portable radon instrumentation (AlphaGUARD DF 2000, Germany) via $\alpha$-decay accounts with a measurement range of $0.002-2000 \mathrm{~Bq} / \mathrm{L}$, and measurement precision of $\pm 3 \%$ o. ${ }^{222} \mathrm{Rn}$ was measured in situ or within three hours (after sampling) to minimize the risk of losing radon from radioactive decay. Water ${ }^{222} \mathrm{Rn}$ activities after measuring $(A)$ need to be corrected to the activities at the time of sampling $\left(A_{0}\right)$.

$$
A_{0}=\frac{A}{e^{-\lambda t}}
$$

$A_{0},{ }^{222} \mathrm{Rn}$ activities at sampling, $A,{ }^{222} \mathrm{Rn}$ activities at measuring, $\lambda,{ }^{222} \mathrm{Rn}$ radioactive decay coefficient, and $t$ is the time between sampling and measuring.

The measurements of river width, depth, flow velocity, and discharge in a river cross-section were conducted by the acoustic Doppler current profiler (ADCP, RiverSurveyor S5, Sontek company, San Diego, CA, USA) from a moving boat located at the front of $2-3 \mathrm{~km}$ Zhoukou sluice and Shenqiu sluice. 


\subsection{Methods}

\subsubsection{Two Component Mixing Model}

According to the mass conservation theory, a two component mixing model was used to estimate the fraction of groundwater discharged to the river $(f)$ [38-43], defined as:

$$
f=\delta_{g}=\left(C_{D}-C_{U} / C_{g}-C_{U}\right) \times 100 \%
$$

where $C_{U}, C_{D}$, and $C_{g}$ are the river concentrations in upstream, river concentration in downstream, and concentration of groundwater inflow (riparian aquifer). Equation (1) is determined under the following condition: (i) two end-members consist of groundwater and surface water not including other sources of water bodies, (ii) $C_{D}$ lies within the range delimited by the end-member $C_{U}$ and $C_{D}$, and (iii) the changes in radon activities are influenced only by infiltration of surface water/groundwater, and evaporation, gas exchange, radioactive decay, and hyporheic exchange terms to be neglected.

\subsection{2. ${ }^{222}$ Rn Mass-Balance Model}

Based on the mass conservation theory, the ${ }^{222} \mathrm{Rn}$ mass balance model was established to describe the exchange flux between river and groundwater in the front of Zhoukou sluice and Huaidian sluice [44]. The model has taken into account the gas exchange and radioactive decay of ${ }^{222} \mathrm{Rn}$ in both surface water and groundwater.

For the section of surface water, recharge groundwater is: $\left(R n_{d}<R n_{U}\right.$ and $\left.Q_{d}<Q_{u}\right)$

$$
R n_{d} \cdot Q_{d}=\int_{0}^{L} q_{g w} \cdot R n_{g w} \cdot \exp (-\alpha \cdot x) d x+R n_{u} \cdot \exp (-\alpha \cdot L) \cdot Q_{u}
$$

For the section of groundwater discharge into the surface water $\left(R n_{d}>R n_{U}\right.$ and $\left.Q_{d}>Q_{u}\right)$, the following is true.

$$
R n_{d} \cdot Q_{d}=R n_{u} \cdot \exp (-\alpha \cdot L) \cdot Q_{u}-\int_{0}^{L} q_{r} \cdot R n_{g w} \cdot \exp -\alpha \cdot(L-x) d x
$$

where $R n_{u}$ and $R n_{d}$ are the ${ }^{222} \mathrm{Rn}$ activities $\left(\mathrm{Bq} / \mathrm{m}^{3}\right)$ of surface water at the upstream and downstream monitoring sites. $R n_{g w}$ is the average ${ }^{222} \mathrm{Rn}$ activity of riverside groundwater between the upstream and downstream monitoring sites. $Q_{u}$ and $Q_{d}$ are upstream and downstream river discharges $\left(\mathrm{m}^{3} / \mathrm{s}\right)$. $h$ is the average depth $(\mathrm{m})$ of surface water between the two cross-sections. $v$ is the average velocity $(\mathrm{m} / \mathrm{s})$ of surface water between the two cross-sections. $L$ is the distance $(\mathrm{m})$ between the two cross-sections. $\lambda$ is ${ }^{222} \mathrm{Rn}$ radioactive decay coefficient $\left(\lambda=2.08 \times 10^{-6} \mathrm{~s}^{-1}\right)$. $D$ is the molecular diffusion coefficient for ${ }^{222} \mathrm{Rn}$ gas $\left(\mathrm{cm}^{2} / \mathrm{s}\right)\left(-\log \mathrm{D}=\frac{980}{T_{\text {air }}+273.15}+1.59\right.$, and $T_{\text {air }}$ is the air temperature $\left.\left({ }^{\circ} \mathrm{C}\right)\right) . \alpha$ is a total loss coefficient including radioactive decay and gas exchange $\left(\alpha=\frac{\lambda}{v}+\frac{D^{0.5}}{v^{0.5}+h^{1.5}}\right)[45-47]$.

\section{Results}

\subsection{Seasonal-Temporal Variations of Hydro-Chemical Characteristics}

\subsubsection{Chemical Composition}

The statistical summary of hydro-chemical parameters was shown in Figure 4. $\mathrm{pH}$ value is an essential parameter reflecting the characteristics of hydro-chemical balance in water [48]. Overall, $\mathrm{pH}$ measured in surface water varied from 8.15 to 9.34 in the dry season and 7.63-9.65 in the wet season 2019, which indicates an alkaline condition. The riparian groundwater showed a weak acidity nature to a slightly alkaline nature with $\mathrm{pH}$ ranging from 6.97 to 8.01 for the dry season and 6.69-7.94 for the wet season with mean $\mathrm{pH}$ values of 7.39 and 7.13, respectively. The causes of relatively high $\mathrm{pH}$ values 
in the surface water is that eutrophication leads to algal blooms, which results in a rise in the dissolved oxygen and high consumption of inorganic carbon.

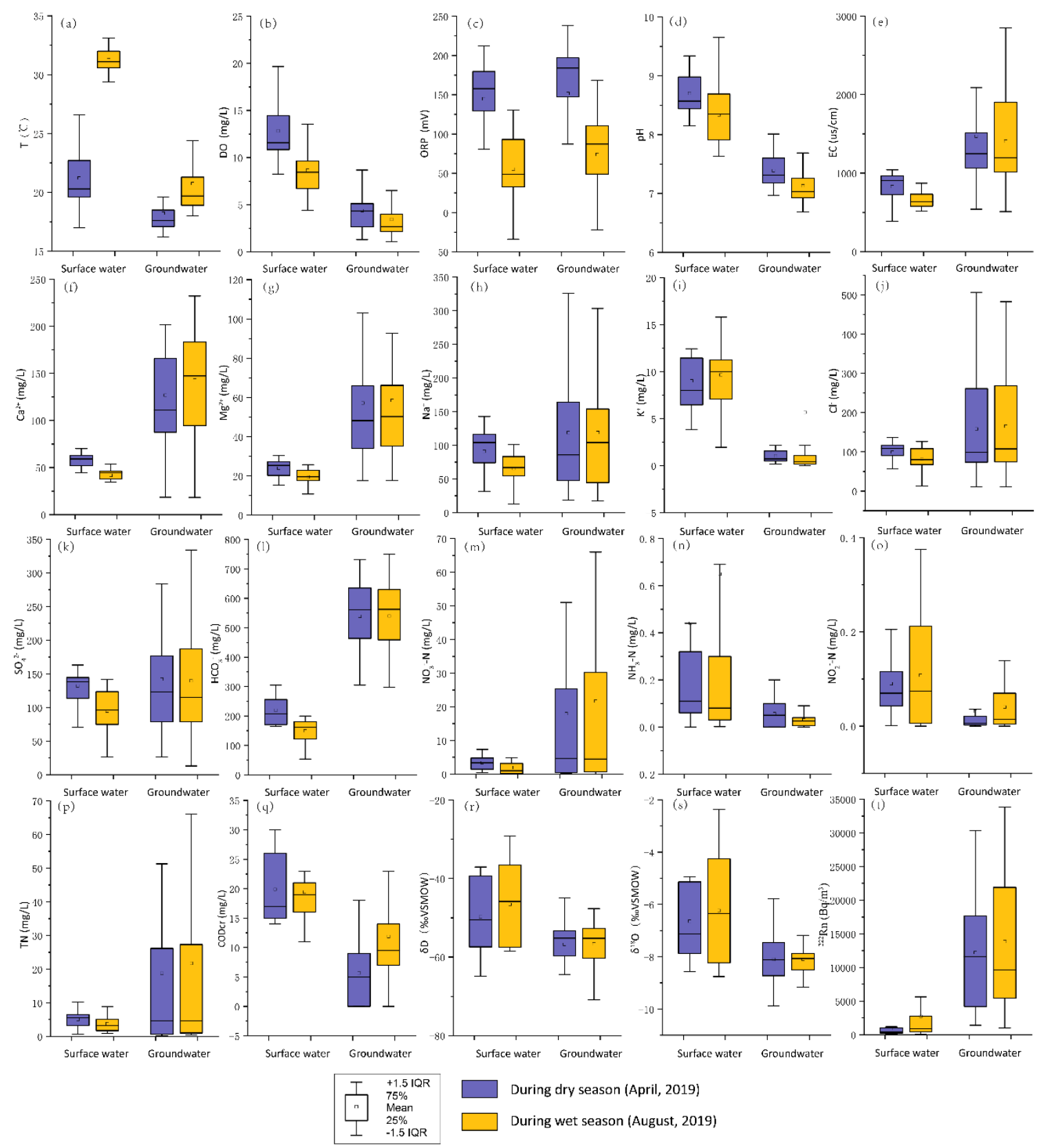

Figure 4. The difference of the indicators in the surface water and groundwater between the dry season and the wet season $(\mathbf{a}-\mathbf{1})$.

The temperature $(\mathrm{T})$ in surface water ranged between 17 and $26.6^{\circ} \mathrm{C}\left(21.2^{\circ} \mathrm{C}\right.$ on average $)$ during the dry season and between 29.4 and $33.1{ }^{\circ} \mathrm{C}\left(31.3^{\circ} \mathrm{C}\right.$ on average) during the wet season. No significant variation of temperature was observed in riparian groundwater between the two seasons. Dissolved oxygen (DO) measured in the surface water during the dry and wet season varied, which ranged from 8.25 to $19.66 \mathrm{mg} / \mathrm{L}$ and from 4.41 to $17.2 \mathrm{mg} / \mathrm{L}$, and mean concentration was 12.84 and $8.64 \mathrm{mg} / \mathrm{L}$, respectively. While the $\mathrm{DO}$ concentration of groundwater has a variation coefficient ranging from 1.28 to $9.33 \mathrm{mg} / \mathrm{L}$ and 1.08 to $8.13 \mathrm{mg} / \mathrm{L}$ for the dry and wet season, respectively. Hence, the riparian groundwater was mostly under an an-oxidized environment, and both surface water and groundwater 
had a more an-oxidized environment in the dry season than during the wet season. Furthermore, the oxidation-reduction potential (ORP) has the same trend, which also conforms to this feature.

There was an apparent correlation between electrical conductivity (EC) and calculated total dissolved solid (TDS) $(\mathrm{R} 2=0.98, p<0.001)$, which implies that the parameters measure in situ and are lab matched very well. EC in surface water values for the dry season varied from 387 to $1040 \mu \mathrm{S} / \mathrm{cm}$ with an average of $827 \mu \mathrm{S} / \mathrm{cm}$ and characterized by lower values ranging from 241 to $871 \mu \mathrm{S} / \mathrm{cm}$ with an average of $618.5 \mu \mathrm{S} / \mathrm{cm}$ during the wet season. EC could reflect the pollutant migration process in the river channel, according to the EC variation shown in Figure 5. The lowest EC value occurred in the Jiangang Reservoir (J1) for both seasons $(387 \mu \mathrm{S} / \mathrm{cm}$ during the dry season, $241 \mu \mathrm{S} / \mathrm{cm}$ during the wet season). Moreover, EC concentration in the Suoxu River and the upper Jialu River (T1, T2, $\mathrm{J} 1$ and J2) were relatively low and increased along the river channel due to the amount of domestic sewage discharge into surface water, which reached up to 765 and $1040 \mu \mathrm{S} / \mathrm{cm}$ in Zhengzhou city (location J3). The concentrations of anions and cations are also higher in the dry season than the wet season (Figure 4). This is likely due to ion concentration dilution by heavy precipitation in August. Similarly, EC in groundwater displayed an identical trend that varied from 539-3680 $\mu \mathrm{S} / \mathrm{cm}$ in April and $510-2850 \mu \mathrm{S} / \mathrm{cm}$ in August. The groundwater observed in Xihua and Shenqiu county (J8-4 and SY2-1) has a high EC level (3680 and $3270 \mu \mathrm{S} / \mathrm{cm}$, respectively), where both $\mathrm{Cl}^{-}$and $\mathrm{NO}_{3}{ }^{-}-\mathrm{N}$ are also very high and reach 610 and $99 \mathrm{mg} / \mathrm{L}$ in Xihua county and 506 and $146 \mathrm{mg} / \mathrm{L}$ in Shenqiu county, respectively. The extreme values could result from the anthropic origin such as domestic sewage discharge or the usage of ammonium chloride fertilizer in the nearby cultivated area $[49,50]$.

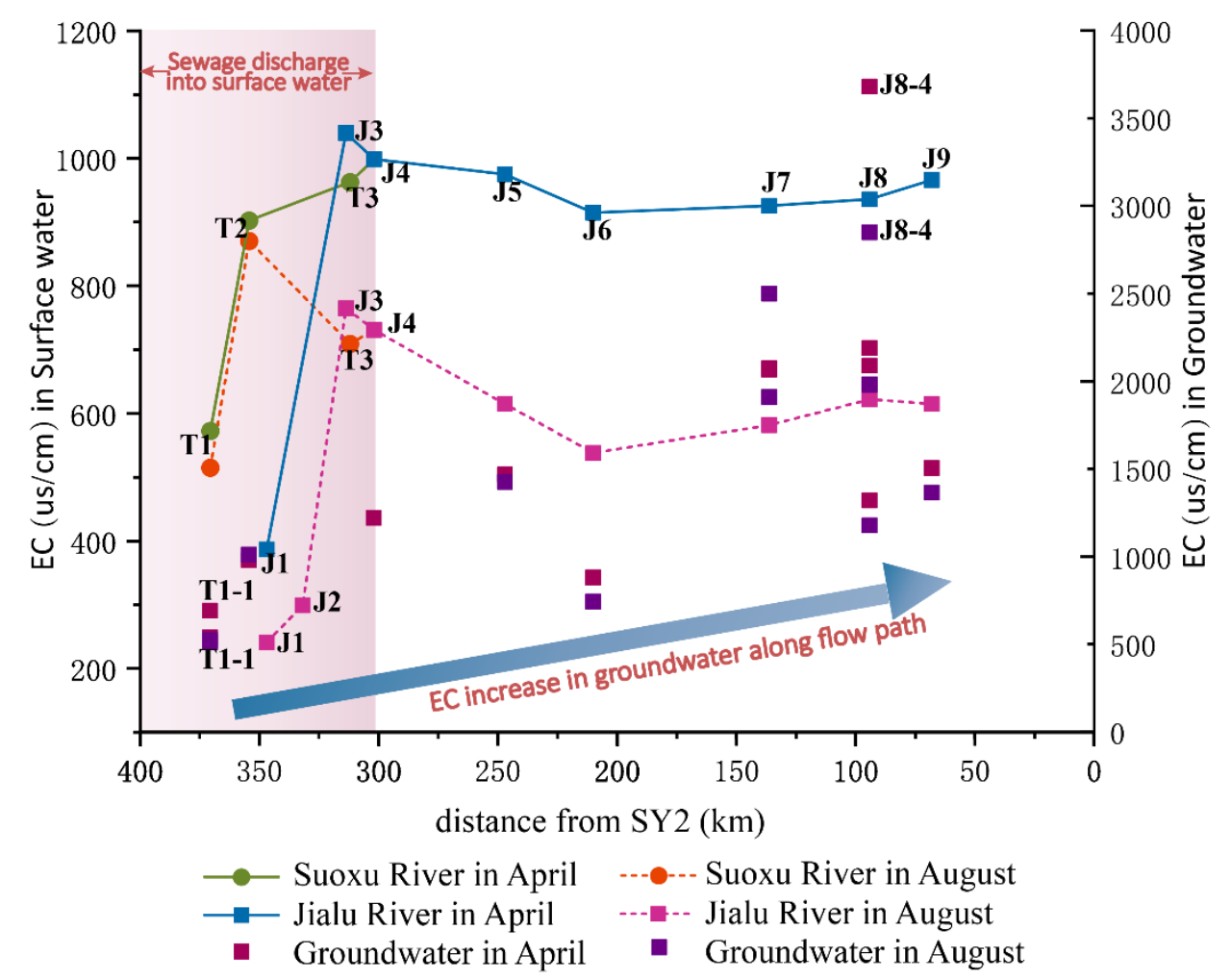

Figure 5. The distance from SY2 (Shenqiu county) profiles for electrical conductivity in the Jialu River.

Depending on hydro-chemical data, water samples were plotted on Triangular diagrams (Figure 6) [51,52]. For surface water, the distribution of cations and anions are relatively concentrated and the dominant type of cation is $\mathrm{Na}-\mathrm{Ca}$, which takes approximately up to $66 \%$ of samples $(n=41)$. In contrast, the anion type is $\mathrm{HCO}_{3}-\mathrm{Cl}_{-}-\mathrm{SO}_{4}$ and $\mathrm{HCO}_{3}-\mathrm{Cl}$, which accounts for $32 \%$ and $17 \%$, respectively. For riparian groundwater, the cation type is dominated by $\mathrm{Ca}$ and Ca-Mg type, which takes up $25 \%$ and $26 \%$, respectively. The anion type is predominated by the $\mathrm{HCO}_{3}$ and $\mathrm{HCO}_{3}-\mathrm{Cl}$ type, which accounted 
for $41 \%$ and $25 \%$, respectively. There is no clear change in the chemical composition in groundwater between the dry and the wet season. Moreover, the major ions of riparian groundwater indicated the consistency in Shangshui county (S3-1, S3-2, and S3-3) and Xihua county (J8-1, J8-2, and J8-4) (Table S1). When taking into account the salinity, the water samples were plotted on Total Ionic Salinity (TIS) (Figure 7a). For surface water (river and lake samples), their majority present a TIS between 0-40 meq/L. For groundwater, a TIS between $20-80 \mathrm{meq} / \mathrm{L}$ is observed. The groundwater in Shenqiu (SY2-2), Xihua (J8-1, J8-2, and J8-4) and Fugou (J7-1 and J7-2) have relatively higher TIS, above 40 meq/L, whereas most other samples have much lower TIS ( $<40$ meq/L).
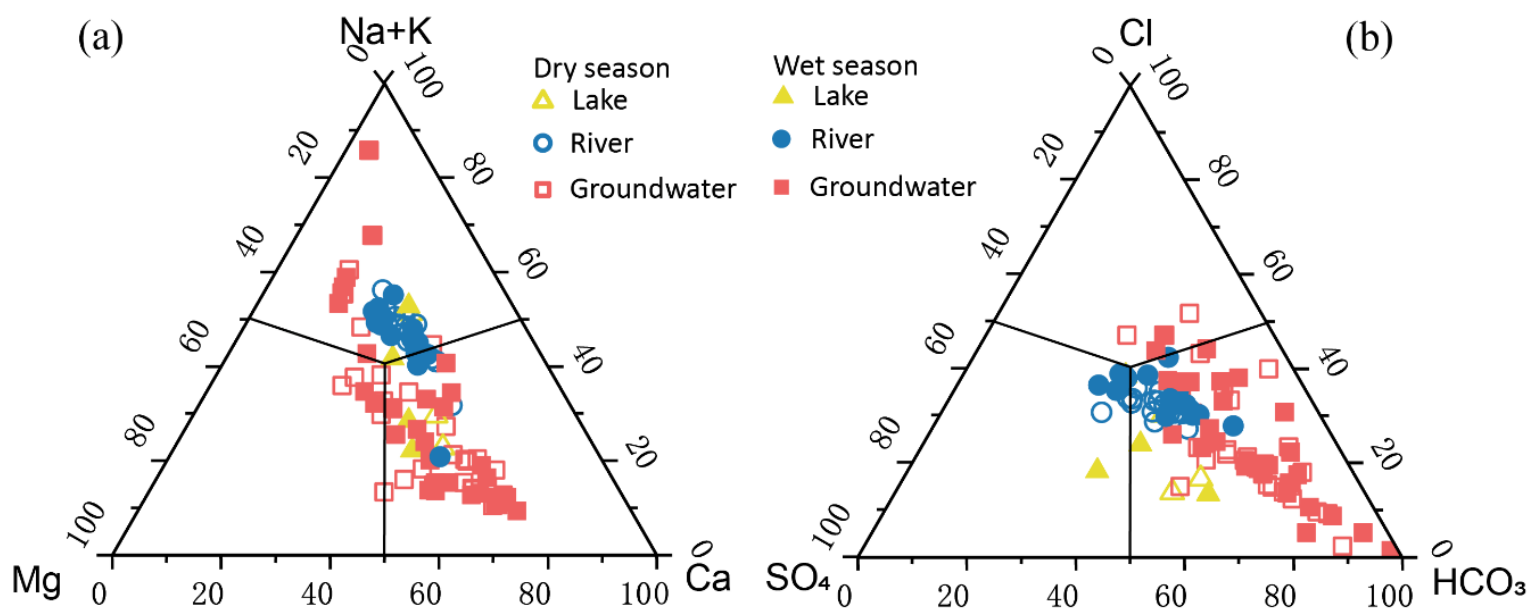

Figure 6. Triangular diagrams of (a) major cations and (b) major anions of water samples in the study area.
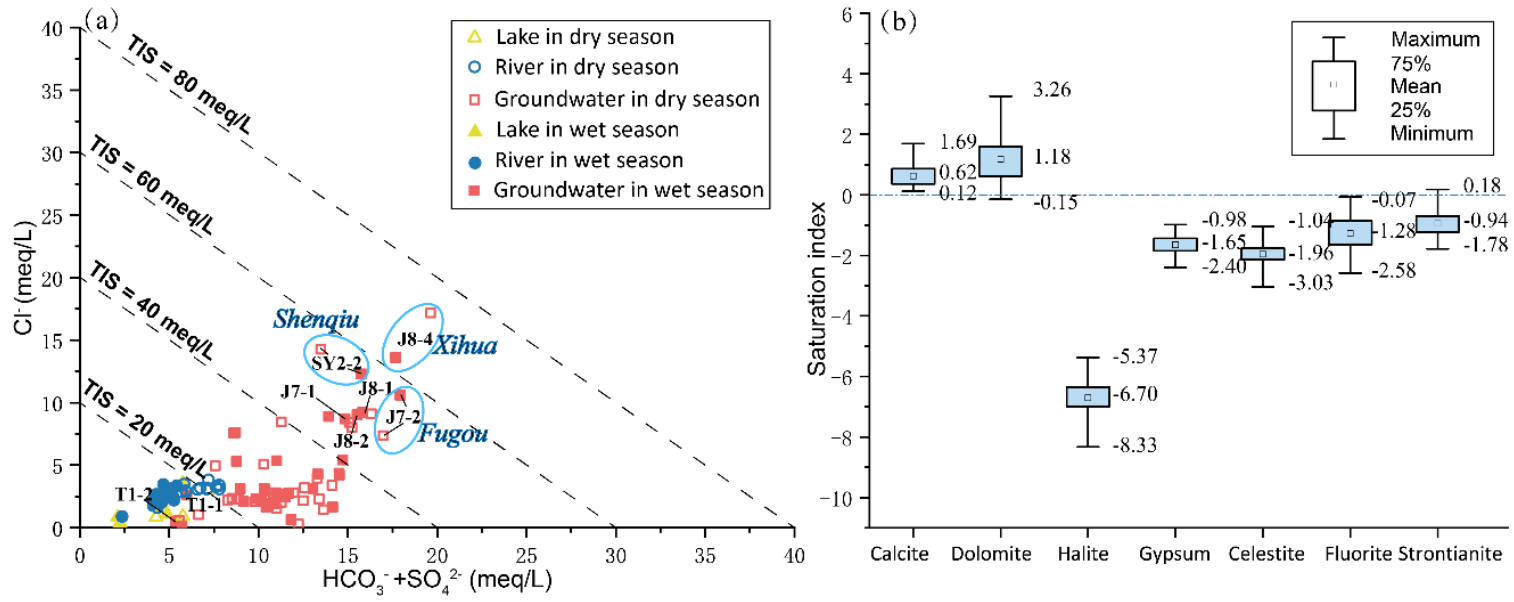

Figure 7. (a) Total Ionic Salinity (TIS) diagram. (b) Box-plot for saturation indices.

Phreeqc software [53] was used to assess the saturation indices for the groundwater samples. The results displayed by box-plot (Figure $7 \mathrm{~b}$ ). The values of $\mathrm{SI}_{\text {calcite }}$ and $\mathrm{SI}_{\text {dolomite }}$ with the uncertainty of \pm 0.5 and \pm 0.1 units, respectively, were above zero. In contrast, others $\left(\mathrm{SI}_{\text {gypsum, }}, \mathrm{SI}_{\text {halite, }}, \mathrm{SI}_{\text {celesite, }}\right.$ and $\mathrm{SI}_{\text {strotianite }}$ ) were negative, among which the values of $\mathrm{SI}_{\text {halite }}$ was far below zero. It confirms that most water samples were oversaturated or close to equilibrium with respect to calcite and dolomite in contrast to gypsum, halite, celesite, and strontianite that did not reach equilibrium and still can be dissolved into water. Additionally, there were insufficient gypsum, halite, celesite, and strontianite mineral sources in this study area, which results in limited interactions between groundwater and these minerals. 


\subsubsection{Nitrogen Species}

The water quality and nitrogen concentration in the surface water and riparian groundwater samples in the study area were summarized in Figure 4. TN is the sum of DIN $\left(\mathrm{NO}_{2}-\mathrm{N}_{2} \mathrm{NH}_{3}-\mathrm{N}\right.$, and $\mathrm{NO}_{3}-\mathrm{N}$ ) and DON.

The concentration of $\mathrm{TN}, \mathrm{NO}_{3}-\mathrm{N} \mathrm{NH}_{3}-\mathrm{N}$, and $\mathrm{NO}_{2}-\mathrm{N}$ for surface water samples ranged from 0.63 to $10.16 \mathrm{mg} / \mathrm{L}, 0.41$ to $7.31 \mathrm{mg} / \mathrm{L}, 0$ to $4.00 \mathrm{mg} / \mathrm{L}$, and $0.001-0.310 \mathrm{mg} / \mathrm{L}$ and averaged $5.02,3.44$, 0.441 , and $0.09 \mathrm{mg} / \mathrm{L}$, respectively, in the dry season while from 0.9 to $11.96 \mathrm{mg} / \mathrm{L}, 0$ to $8.21 \mathrm{mg} / \mathrm{L}$, 0 to $9.00 \mathrm{mg} / \mathrm{L}$, and $0-0.375 \mathrm{mg} / \mathrm{L}$ and averaged $3.76,1.92,0.649$, and $0.108 \mathrm{mg} / \mathrm{L}$, respectively, during the wet season. No significant difference of $\mathrm{NH}_{3}-\mathrm{N}$ and $\mathrm{NO}_{2}-\mathrm{N}$ was detected between the two seasons (Paired $t$-test, $N=19, p>0.05$, Figure 4). $\mathrm{TN}$ and $\mathrm{NO}_{3}-\mathrm{N}$ concentrations in surface water were found to be lower during the wet season than during the dry season, which might be due to the effect of rainfall dilution and high microbial activity. Moreover, the $\mathrm{NH}_{3}-\mathrm{N}$ concentration exceeded the maximum contaminant levels $(0.16 \mathrm{mg} / \mathrm{L})$ of World Health Organiztion $(\mathrm{WHO})$ in $39 \%$ of the surface water samples. The CODcr concentration in this study during the dry season in surface water $(N=19$, $22 \pm 8 \mathrm{mg} / \mathrm{L})$ and during the wet season in surface water $(N=22,24 \pm 17 \mathrm{mg} / \mathrm{L})$ is used as a proxy indicator of organic pollutants in the water environment. The CODcr concentration in more than $44 \%$ of surface water samples was well above $20 \mathrm{mg} / \mathrm{L}$, which is the limit set for class III under the Chinese Surface Water Quality Standard (GB3838-2002).

The spatial distribution of nitrogen species in the surface water of SRB was shown in Figure 8. The concentrations of $\mathrm{TN}, \mathrm{NO}_{3}-\mathrm{N} \mathrm{NH}_{3}-\mathrm{N}$, and $\mathrm{NO}_{2}-\mathrm{N}$ in the Jialu River were $5.40 \pm 4.76 \mathrm{mg} / \mathrm{L}$, $3.86 \pm 3.45 \mathrm{mg} / \mathrm{L}, 2.00 \pm 2.00 \mathrm{mg} / \mathrm{L}$, and $0.156 \pm 0.155 \mathrm{mg} / \mathrm{L}$, respectively, in the dry season, whereas they were $6.43 \pm 5.52 \mathrm{mg} / \mathrm{L}, 4.20 \pm 4.02 \mathrm{mg} / \mathrm{L}, 4.51 \pm 4.50 \mathrm{mg} / \mathrm{L}$, and $0.189 \pm 0.186 \mathrm{mg} / \mathrm{L}$, respectively, in the wet season. The nitrogen pollution in the Sha River and the Ying River were light, where the $\mathrm{NH}_{3}-\mathrm{N}$ concentration was well below the maximum contaminant levels $(\mathrm{MCL})$ of $\mathrm{WHO}(0.16 \mathrm{mg} / \mathrm{L})$. The degree of nitrogen species' pollution was higher in the Shaying River than in the Sha and Ying River. Therefore, the Jialu River, with the highest level of nitrogen in both seasons, should be the main nitrogen contributor to the mainstream of the Shaying River due to the low level of TN in other tributaries (the Sha River and the Ying River). As for the serious nitrogen pollution river, the TN level exceeded the limit set for class V under the Chinese Surface Water Quality Standard (GB3838-2002), $2 \mathrm{mg} / \mathrm{L}$ suitable for use as a water supply in the agricultural area, and general landscape except for the upper stream (J1 and J2). The Suoxu River, with the highest level of ammonium nitrogen (T3: $4 \mathrm{mg} / \mathrm{L}$ and $9 \mathrm{mg} / \mathrm{L}$, respectively), should be the main ammonium contributor to the mainstream of the Jialu River due to the low level of ammonium in the upper stream of the Jialu River before meeting the Suoxu River (J1 and J2). Lastly, unlike in the other rivers, $\mathrm{NH}_{3}-\mathrm{N}$ was found to be a high proportion of $\mathrm{TN}$ in Suoxu River (T1 and T3) compared to $\mathrm{NO}_{3}-\mathrm{N}$.

For riparian groundwater samples, the concentration of $\mathrm{TN}, \mathrm{NO}_{3}-\mathrm{N}, \mathrm{NH}_{3}-\mathrm{N}$, and $\mathrm{NO}_{2}-\mathrm{N}$ ranged from 0.24 to $164.26 \mathrm{mg} / \mathrm{L}, 0.23$ to $148.64 \mathrm{mg} / \mathrm{L}, 0$ to $0.20 \mathrm{mg} / \mathrm{L}$, and $0-0.21 \mathrm{mg} / \mathrm{L}$ and averaged 18.80 , $17.96,0.057$, and $0.031 \mathrm{mg} / \mathrm{L}$, respectively, during the dry season while, from 0.37 to $133.07 \mathrm{mg} / \mathrm{L}, 0$ to $133.05 \mathrm{mg} / \mathrm{L}, 0$ to $0.11 \mathrm{mg} / \mathrm{L}$, and $0-0.206 \mathrm{mg} / \mathrm{L}$ and averaged $21.95,21.64,0.03$, and $0.041 \mathrm{mg} / \mathrm{L}$, respectively, during the wet season. $\mathrm{TN}, \mathrm{NO}_{3}-\mathrm{N}$, and $\mathrm{NO}_{2}-\mathrm{N}$ were not significantly different between seasons (Paired $t$-test, $\mathrm{N}=30, p>0.05$ ). $\mathrm{NO}_{2}-\mathrm{N}$ was easily oxidized to $\mathrm{NO}_{3}-\mathrm{N}$ due to the fast conversion by nitrobacteria, which leaves low $\mathrm{NO}_{2}-\mathrm{N}$ concentrations in both surface water and groundwater during the two seasons. Based on the observation, $\mathrm{NH}_{3}-\mathrm{N}$ and $\mathrm{NO}_{2}-\mathrm{N}$ concentrations were much lower than the $\mathrm{NO}_{3}-\mathrm{N}$ concentrations. Hence, $\mathrm{NO}_{3}-\mathrm{N}$ was the dominant inorganic $\mathrm{N}$ species in groundwater in the SRB. The CODcr concentration in this study during the dry season in groundwater $(N=31$, $9 \pm 9 \mathrm{mg} / \mathrm{L})$ and wet season in groundwater $(N=30,20 \pm 20 \mathrm{mg} / \mathrm{L})$. Meanwhile, the level of CODcr in groundwater was significantly different between seasons (Paired $t$-test, $\mathrm{t}(30)=-3.09, p=0.004$ ). The CODcr concentration in groundwater during the wet season (mean $11.87 \mathrm{mg} / \mathrm{L}$ ) was higher than those during the dry season (mean $5.68 \mathrm{mg} / \mathrm{L}$ ). Overall, the degree of $\mathrm{NH}_{3}-\mathrm{N}$ pollution was lower in groundwater (only one sample exceeded $0.16 \mathrm{mg} / \mathrm{L})$ than in surface water $(39 \%$ of the total samples 
$(N=41))$. However, the degree of $\mathrm{NO}_{3}-\mathrm{N}$ pollution was found to be higher in riparian groundwater than in surface water, which exceeds the acceptable limits for drinking water recommended $(10 \mathrm{mg} / \mathrm{L})$ by WHO [54], which accounted for $40 \%$ of the total samples $(N=61)$. Areas with higher concentrations (above $10 \mathrm{mg} / \mathrm{L}$ ) in riparian groundwater were mainly distributed at the lower reaches of Jialu River and Shenqiu county of Shaying River.

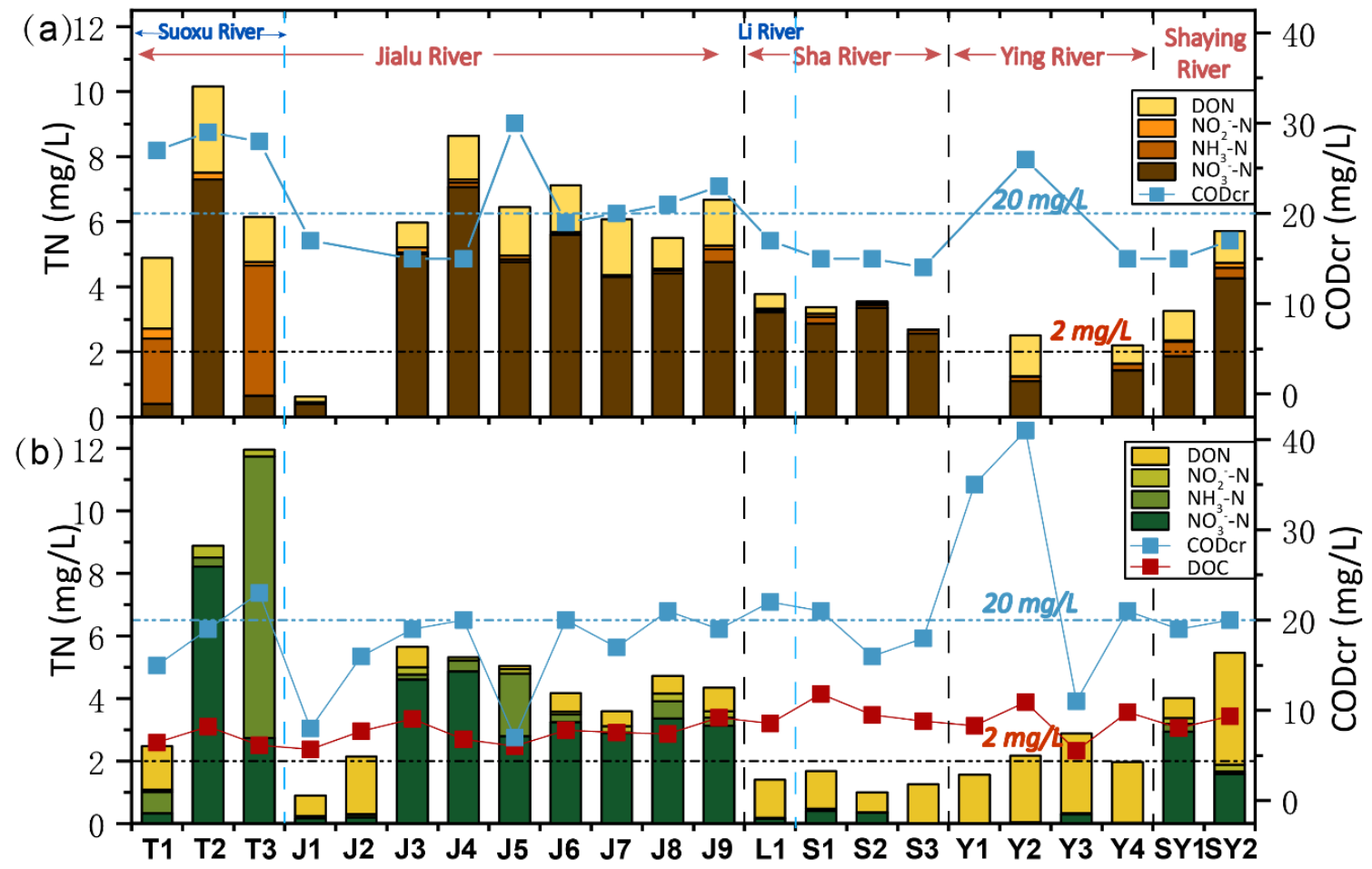

Figure 8. Variations of $\mathrm{TN}, \mathrm{NO}_{2}-\mathrm{N}, \mathrm{NH}_{3}-\mathrm{N}, \mathrm{NO}_{3}-\mathrm{N}, \mathrm{CODcr}$, and DOC concentration of surface water. (a) Wet season. (b) Dry season.

\subsection{Seasonal-Temporal Variations of Isotopic Characteristics}

\subsection{1. ${ }^{2} \mathrm{H}$ and ${ }^{18} \mathrm{O}$}

The stable isotopes of oxygen-18 $\left({ }^{18} \mathrm{O}\right)$ and deuterium $\left({ }^{2} \mathrm{H}\right.$ or $\left.\mathrm{D}\right)$ are ideal conservative tracers for determining the origin of groundwater by investigating the water circulation and movement, revealing the relationship between local elevation and stable isotopes, and understanding the groundwater and surface water interaction [12,55-60]. The local meteoric water line (LMWL) was given by $\delta \mathrm{D}=6.75$ $\delta^{18} \mathrm{O}-2.71\left(\mathrm{r}^{2}=0.88, n=57\right)$ based on $\delta^{18} \mathrm{O}$ and $\delta \mathrm{D}$ values of rainfall from 1985 to 1992 located in Zhengzhou $\left(34^{\circ} 72^{\prime} \mathrm{N}, 113^{\circ} 65^{\prime} \mathrm{E}\right)$ [61]. Since the slope of LWML was lower than the global meteoric water line, the process of sub-cloud evaporation should also have an impact on precipitation [62]. The isotopic data $\left(\delta^{18} \mathrm{O}\right.$ and $\left.\delta \mathrm{D}\right)$ of the samples collected from surface water (river and lake) and groundwater were presented in relation to the LMWL in Figure 9, which indicates meteoric origin. The linear regression line of $\delta^{18} \mathrm{O}$ and $\delta \mathrm{D}$ for water samples was described by $\delta \mathrm{D}=5.84 \delta^{18} \mathrm{O}-10.02\left(\mathrm{R}^{2}=0.95\right)$ during the dry season and by $\delta \mathrm{D}=5.36 \delta^{18} \mathrm{O}-13.20\left(\mathrm{R}^{2}=0.97\right)$ during the wet season.

In the study area, the surface water samples presented an isotopic composition ranging from 64.9 to $-37.1 \%$ o (average $-49.7 \%$ ) for $\delta \mathrm{D}$ and from -8.58 to $-4.94 \%$ (average $-6.65 \%$ ) for $\delta^{18} \mathrm{O}$ during the dry season while from -58.5 to $-29.2 \%$ (average $-46.5 \%$ ) for $\delta \mathrm{D}$ and from -8.76 to $-2.37 \%$ o (average $-6.23 \%$ ) for $\delta^{18} \mathrm{O}$ during the wet season. Moreover, the isotopic values of riparian groundwater samples ranged from $-69.8 \%$ o to $-44.9 \%$ o (mean $-56.7 \%$ ) for $\delta \mathrm{D}$, and from $-9.88 \%$ o to $-5.79 \%$ o (mean $-8.1 \%$ o) for $\delta^{18} \mathrm{O}$ in the dry season while from $-70.9 \%$ o to $-47.6 \%$ o (mean $-56.6 \%$ ) for $\delta \mathrm{D}$, and from $-9.83 \%$ o to $-6.29 \%$ o (mean $-8.09 \%$ ) for $\delta^{18} \mathrm{O}$ in the wet season. The value of $\delta \mathrm{D}$ 
and $\delta^{18} \mathrm{O}$ were not significantly different for both groundwater and surface water between seasons (Paired $t$-test, $N=19, p>0.05$ ).
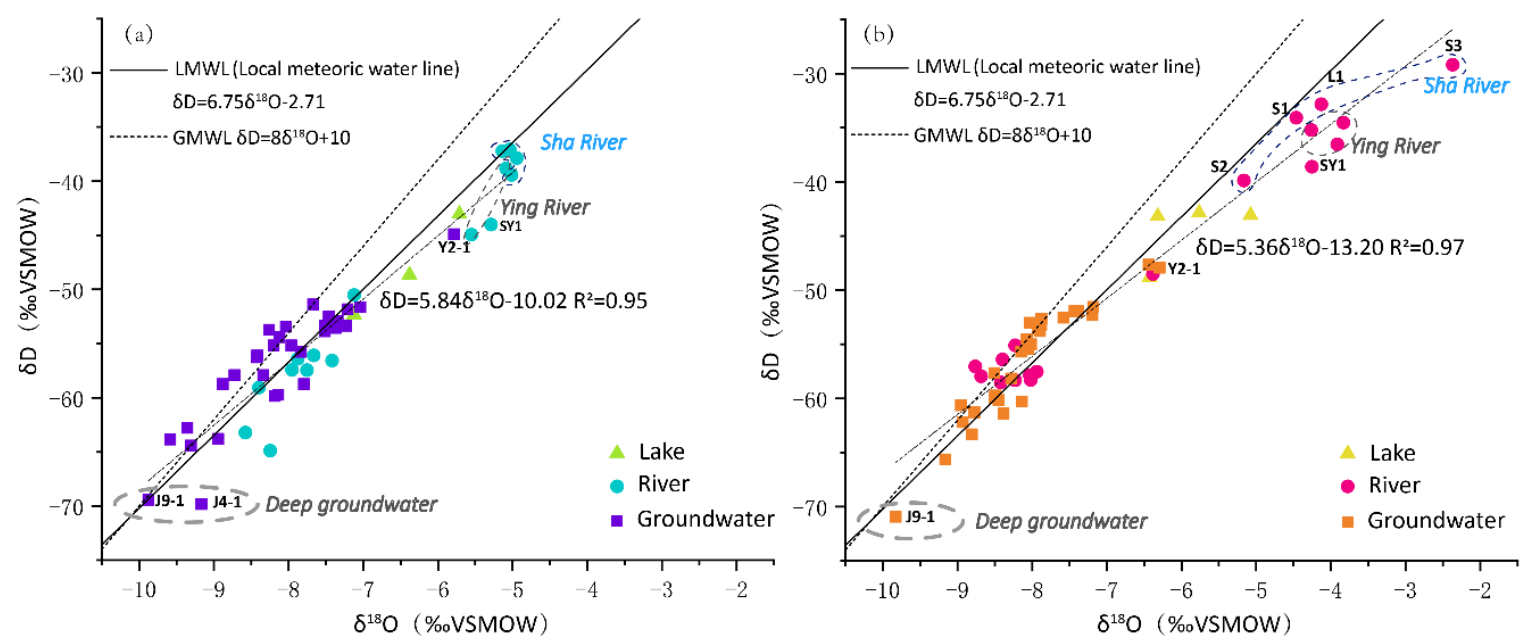

Figure 9. Plot of $\delta^{18} \mathrm{O}$ and $\delta \mathrm{D}$ of various water samples from Shaying River Basin in the dry season (a) and wet season $(\mathbf{b})$.

Figure 9 showed that different types of waters showed distinct isotopic compositions. In general, (i)riparian groundwater samples scattered with a large scale along the global meteoric water line (GMWL) and local meteoric water line (LMWL), which were relatively depleted in isotopes compared to surface water. This could be attributed to different recharge conditions. The groundwater samples J4-1 and J9-1 were both from deep wells (well depth $>50 \mathrm{~m}$ ) and showed very depleted isotopic composition, which revealed little or no evaporative enrichments. Sample J4-1 was characterized by an ${ }^{18} \mathrm{O}$-shift-like change due to water-rock interactions with deep circulation. (ii)The surface water samples were plotted in two centralized locations, the enriched location for the Sha River and Ying River, and the depleted location for the Jialu River. The difference of isotopic compositions between these two locations could result from the different recharge sources with different altitudes and/or recharge temperatures.

The surface water samples obtained in the Jialu River presented a wide range of stable isotopic signatures. The samples of lake and river water had different features of the $\delta \mathrm{D}$ and $\delta^{18} \mathrm{O}$ compositions. Figure 10 showed that heavier isotopes were enriched in the lake (average $-48.00 \%$ ofor $\delta \mathrm{D},-6.40 \%$ o for $\delta^{18} \mathrm{O}$ in the dry season. Average $-44.48 \%$ o for $\delta \mathrm{D},-5.90 \%$ o for $\delta^{18} \mathrm{O}$ in the dry season) than river samples (average $-58.87 \%$ o for $\delta \mathrm{D},-7.98 \%$ o for $\delta^{18} \mathrm{O}$ in the wet season, average $-57.32 \%$ o for $\delta \mathrm{D}$, $-8.31 \%$ o for $\delta^{18} \mathrm{O}$ in the wet season) because of intensive evaporation. The river samples showed a generally increasing trend in the dry season, which indicates an evaporation effect $[39,40]$ along the river stretch from Zhengzhou city. Along the upper reach of the Jialu River, surface water presented a distinct declining trend with more depleted isotopes from $-43 \%$ o to $-64 \%$ o for $\delta \mathrm{D}$ and $-5 \%$ o to $-8 \%$ o for $\delta^{18} \mathrm{O}$, respectively, as chloride content, nitrogen pollution (Figure 8), and EC increase (Figure 5). This suggests that the values of stable isotopes were affected by external water recharge. The mixing process from a majority of industrial and domestic wastewater appeared to be the external recharge, which had high nitrate and chloride content and more depleted isotopes.

Samples of river and groundwater have distinct compositions of $\delta \mathrm{D}$ and $\delta^{18} \mathrm{O}$ along the Sha River, Ying River, and Shaying River. The river water was with more enriched heavy isotopes than groundwater (Figure 9). Moreover, Figure 10 showed that a drop of river isotopic values from sample S2, Y1, and SY2 could be attributed to the mixing with groundwater discharge featured by more negative isotopic values. 

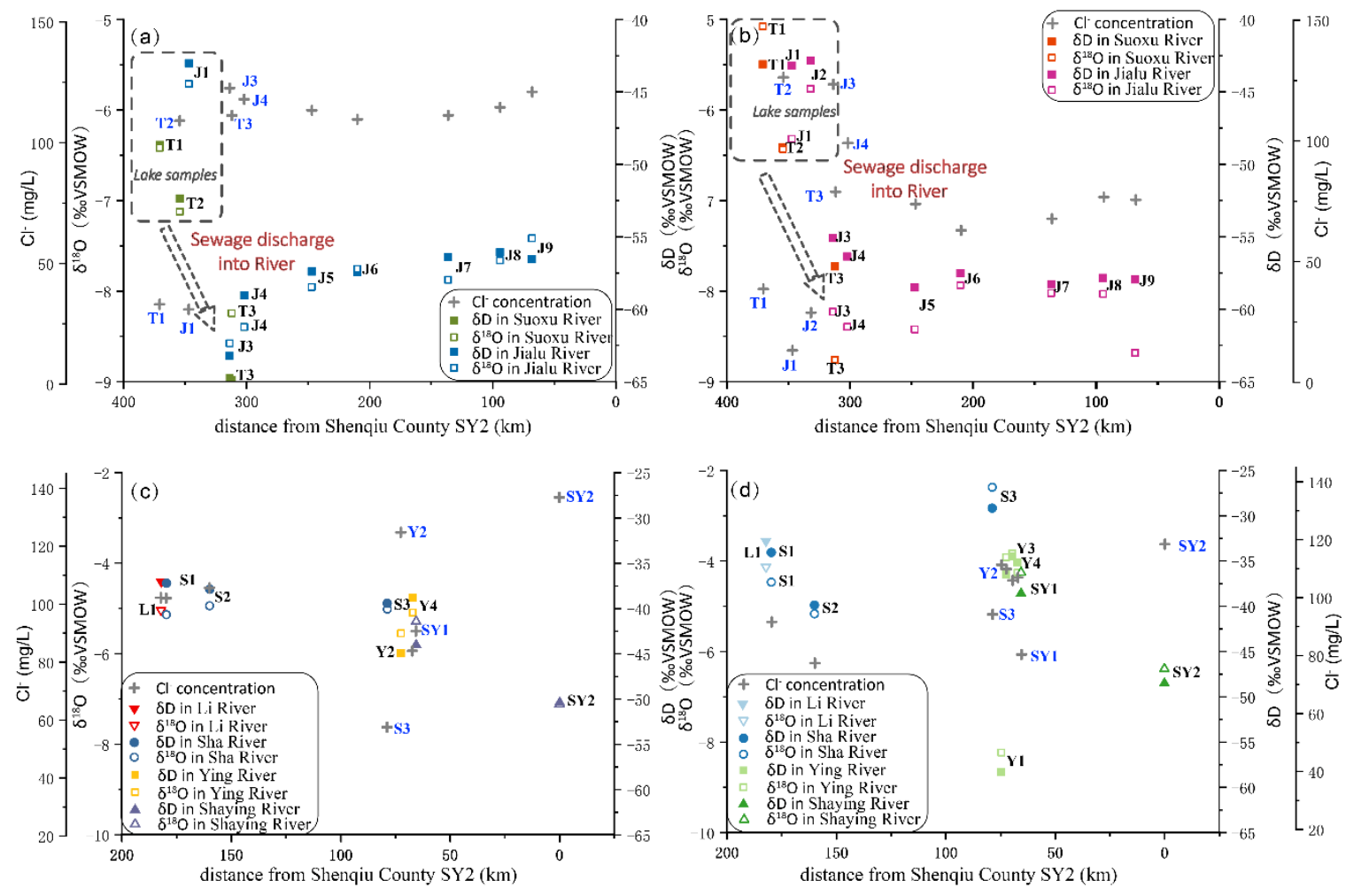

Figure 10. The distance from SY2 (Shenqiu county) profiles for chloride, stable isotopes $\delta \mathrm{D}$, and $\delta^{18} \mathrm{O}$ in the (a) Jialu River in the dry season, (b) Jialu River in the wet season, (c) Shaying River in the dry season, and (d) Shaying River in the wet season.

\subsection{2. ${ }^{222} \mathrm{Rn}$}

Compared with the isotopes of oxygen $-18\left({ }^{18} \mathrm{O}\right)$ and deuterium $\left({ }^{2} \mathrm{H}\right.$ or D) (relatively stable), the radon activity changed dramatically in surface water and groundwater, which revealed the existence of complex hydrologic process [13]. In the SRB, the ${ }^{222} \mathrm{Rn}$ activity values of surface water showed a very large spatial variability, which ranged from 57-3513 for the dry season and 57-12651 $\mathrm{Bq} / \mathrm{m}^{3}$ for the wet season 2019 with an average of $904(n=19)$ and $2755(n=22) \mathrm{Bq} / \mathrm{m}^{3}$, respectively. The groundwater ${ }^{222} \mathrm{Rn}$ activities observed were substantially higher than in surface water samples (around 1-2 orders of magnitude) and they ranged around 1404-30358 Bq $/ \mathrm{m}^{3}$ for the wet season and 970-33,869 Bq/ $/ \mathrm{m}^{3}$ for the dry season 2019 with an average $12201(n=31)$ and $13835(n=31) \mathrm{Bq} / \mathrm{m}^{3}$, respectively. The distribution of the ${ }^{222} \mathrm{Rn}$ activity in surface water and associated groundwater were shown along the Jialu River, Sha River, Ying River, and Shaying River (Figure 11).

Radon activity in the Jialu River range from 57 to $2909 \mathrm{~Bq} / \mathrm{m}^{3}$ with an average of $612 \mathrm{~Bq} / \mathrm{m}^{3}$ $(n=11)$ in April and range from 57 to $5610 \mathrm{~Bq} / \mathrm{m}^{3}$ with an average of $940 \mathrm{~Bq} / \mathrm{m}^{3}(n=12)$ in August 2019. The minimum ${ }^{222} \mathrm{Rn}$ activity was observed at Hewang Reservoir (T2) in April as well as August in Suoxu River, which is a main tributary of the Jialu River. In general, ${ }^{222} \mathrm{Rn}$ activity of surface water was less than $2000 \mathrm{~Bq} / \mathrm{m}^{3}$ except for J8 at the Jialu Bridge of Xihua county. The highest activities occurred in both seasons, where ${ }^{222} \mathrm{Rn}$ activities reached 2909 in April and increased to $5610 \mathrm{~Bq} / \mathrm{m}^{3}$ in August 2019. Normally, there is no extra recharge of ${ }^{222} \mathrm{Rn}$ or ${ }^{226} \mathrm{Ra}$ in the natural river except from groundwater or lithology of geological layers. Therefore, changing ${ }^{222} \mathrm{Rn}$ activities at the same locations over the seasons indicate groundwater flux variations. Groundwater ${ }^{222} \mathrm{Rn}$ activities along the Jialu River ranged from 1405 to $19,617 \mathrm{~Bq} / \mathrm{m}^{3}$ with a mean $(n=13)$ of $8427 \mathrm{~Bq} / \mathrm{m}^{3}$ in April and from 970 to 23,681 Bq/m $/ \mathrm{m}^{3}$ with a mean $(n=12)$ of $8682 \mathrm{~Bq} / \mathrm{m}^{3}$ in August 2019. Overall, groundwater ${ }^{222} \mathrm{Rn}$ activities showed a decreasing trend from upstream to Weishi county (J6) along the flow path. The maximum ${ }^{222} \mathrm{Rn}$ concentration was found in sample J7-2 for both seasons, which indicates that ${ }^{222} \mathrm{Rn}$ activity might have different sources that had a high level of ${ }^{222} \mathrm{Rn}$ activity. Groundwater sample 
(J8-4), neighboring Jialu Bridge of Xihua county (J8), had the ${ }^{222} \mathrm{Rn}$ activities 4162 in April and 970 in August 2019. Infiltration irrigation water might have caused groundwater dilution and led to a decrease in ${ }^{222} \mathrm{Rn}$ activity.
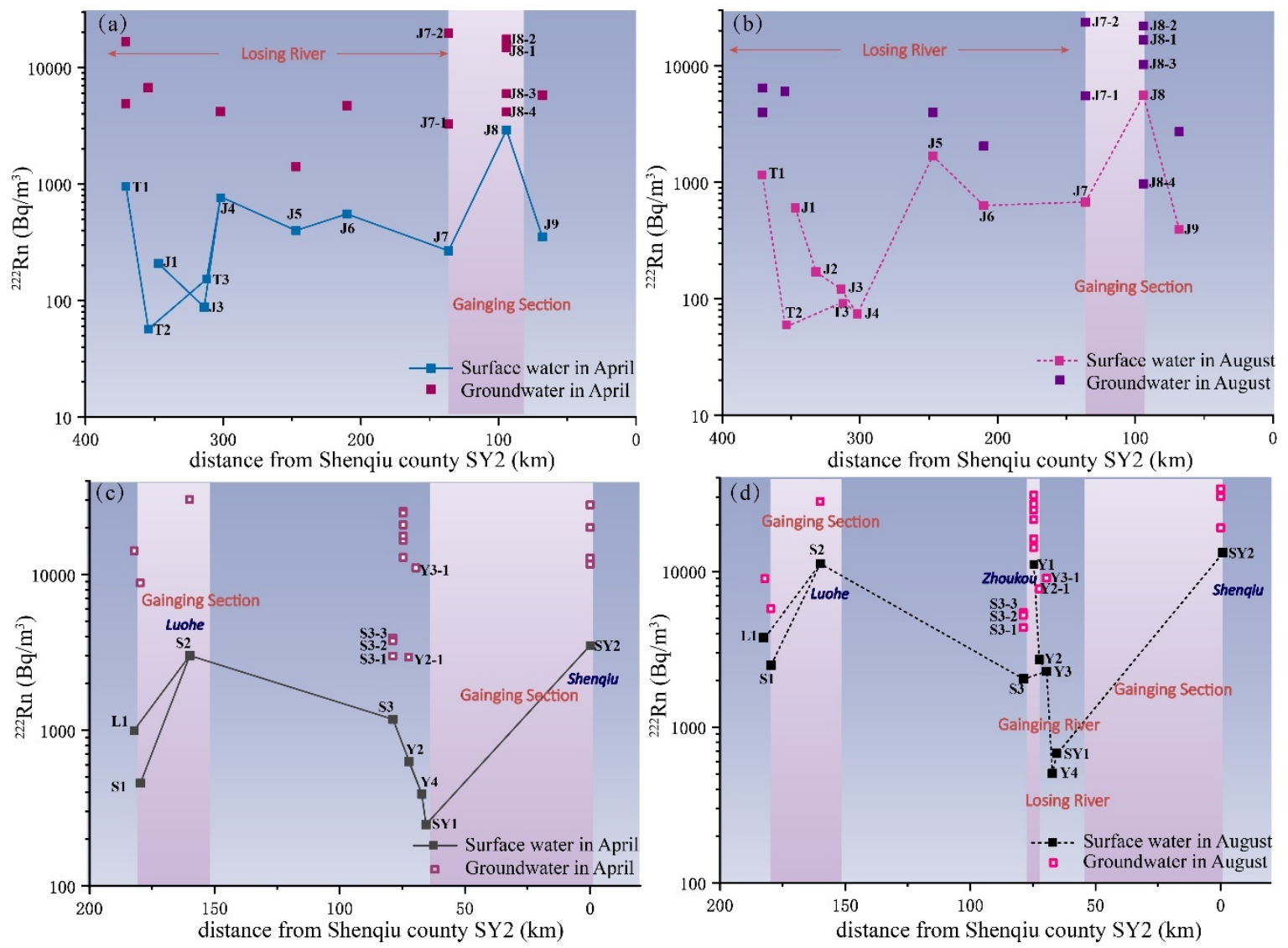

Figure 11. The distance from SY2 (Shenqiu county) profiles for ${ }^{222} \mathrm{Rn}$ activities in the (a) Jialu River in the dry season, (b) Jialu River in the wet season, (c) Shaying River in the dry season, and (d) Shaying River in the wet season.

Activities of ${ }^{222} \mathrm{Rn}$ in the Sha River was generally higher than in Jialu River, and the variation range was $460 \sim 3022 \mathrm{~Bq} / \mathrm{m}^{3}$ with a mean of $1418 \mathrm{~Bq} / \mathrm{m}^{3}(n=4)$ in April and $2040 \sim 11,228 \mathrm{~Bq} / \mathrm{m}^{3}$ with a mean of $4882 \mathrm{~Bq} / \mathrm{m}^{3}(n=4)$ in August. From the sampling point L1 and S1 to S2, radon activity increases rapidly from 460 to $3022 \mathrm{~Bq} / \mathrm{m}^{3}$ in April and from 2503 to 11,228 Bq/m $\mathrm{m}^{3}$ in August, respectively. High ${ }^{222} \mathrm{Rn}$ activities are associated with groundwater discharge or bank return flow to the river. It can be inferred that there was groundwater inflow with high radon activity near S2. For groundwater, the ${ }^{222} \mathrm{Rn}$ activity trends were very similar to surface water. It dropped from 30,580 to $2998 \mathrm{~Bq} / \mathrm{m}^{3}$ and from 28,040 to $4348 \mathrm{~Bq} / \mathrm{m}^{3}$, respectively, along the flow path between S2 and S3, which might be resulted from the distinct ${ }^{226} \mathrm{Ra}$ contents in aquifer materials in different locations along the groundwater flow path. Along the Ying River, the ${ }^{222} \mathrm{Rn}$ activity decreased rapidly from 10,989 to $505 \mathrm{~Bq} / \mathrm{m}^{3}$ in August. This phenomenon could be attributed to ${ }^{222} \mathrm{Rn}$ loss from the radioactive decay and gas exchange. The high ${ }^{222} \mathrm{Rn}$ activity at $\mathrm{Y} 1$ indicated extra recharge of ${ }^{222} \mathrm{Rn}$ had joined into the river in this zone. For groundwater, the minimum ${ }^{222} \mathrm{Rn}$ activity in both seasons was simultaneously found in sample Y2-1, 2593 in April, and $7703 \mathrm{~Bq} / \mathrm{m}^{3}$ in August 2019, respectively, which suggests that groundwater at Y2-1 received adjacent river (Y2) recharge as one of its primary origins in April. Along the Shaying River, ${ }^{222} \mathrm{Rn}$ activity gradually increased from 248 to $3513 \mathrm{~Bq} / \mathrm{m}^{3}$ in April and from 666 to 12,651 Bq/m in August, respectively, along the flow path, which suggests that surface water (S2) received the groundwater discharge and groundwater inflow flux varied over two seasons. 


\section{Discussion}

\subsection{Hydrologic Process of Riparian Groundwater}

In this study, environmental tracers (including hydro-chemical parameter, stable isotopes ${ }^{18} \mathrm{O}$ and ${ }^{2} \mathrm{H}$, and the dissolved gasses ${ }^{222} \mathrm{Rn}$ ) were used to recognize river losing zones and river gaining zones in SRB. According to the above discussions, there were two river losing zones (zones that groundwater received river recharge) that were recognized. One was along the upstream of the Jialu River. The ${ }^{222} \mathrm{Rn}$ activity was relatively low in the upper and middle catchments (from T1 to J6, Zhengzhou and Kaifeng city) of river and adjacent aquifer. Meanwhile, groundwater with low EC (less than $1500 \mu \mathrm{S} / \mathrm{cm}$ ) was also mainly concentrated in this area (Figure 5), which indicates that riparian groundwater receives surface water recharge during the sampling period. Our findings were in agreement with the previous research from Reference [63] that the river stage was higher than the groundwater table in 2015 due to groundwater over-exploration in rapid urbanization. The other one was along the downstream of the Ying River (Y2-Y4). First, the ${ }^{222} \mathrm{Rn}$ activity in riparian groundwater (Y2-1) sharply decreased to $2953 \mathrm{~Bq} / \mathrm{m}^{3}$ in April, which could be due to mixing with river water of low ${ }^{222} \mathrm{Rn}$ activity. Second, the stable isotopic composition in groundwater became more enriched and whose values closed to the rivers (Figure 9), which suggests groundwater mixing with the river. Furthermore, the hydro-chemical parameters also showed likely changes that might be affected by this kind of interaction. The hydro-chemical type of groundwater changed from the $\mathrm{HCO}_{3}-\mathrm{Ca}-\mathrm{Mg}$ types to the $\mathrm{HCO}_{3}-\mathrm{Cl}-\mathrm{Na}-\mathrm{Ca}$ types, which showed an increase of $\mathrm{Cl}^{-}$and $\mathrm{Na}^{+}$proportions that might be due to mixing with the $\mathrm{Cl}-\mathrm{SO}_{4}-\mathrm{HCO}_{3}-\mathrm{Na}-\mathrm{Ca}$ type of river. ${ }^{222} \mathrm{Rn}$ activity used to locate river gaining zones (zones that the river gained water from groundwater discharge), as it rapidly removed in the surface water by radioactive decay and degassing. The calculated mixing ratios of surface water and groundwater at two sampling times were presented in Table 1. Along the Jialu River, the highest river ${ }^{222} \mathrm{Rn}$ activities observed in the lower reaches at Xihua county (J8), suggested the river receives groundwater influxes and the fraction of groundwater was approximately $15.37 \%$ in April and $23.23 \%$ in August 2019. Along the Ying River, river samples (Y1) were recharged by groundwater as shown by the measurements of ${ }^{222} \mathrm{Rn}, \delta \mathrm{D}$, and $\delta^{18} \mathrm{O}$. The fraction of groundwater was high (72.14-94.26\%), which showed a significant amount of groundwater discharge into the river during the wet season. Along the Sha River, there is groundwater inflow with high radon activity near luohe city (S2), which corresponded to elevated EC and more depleted $\delta \mathrm{D}$. The fraction of groundwater was around 4.58-8.37\% in April and 30.77-32.51\% in August 2019. Along the Shaying River, the substantial elevated ${ }^{222} \mathrm{Rn}$ activity at Shenqiu county (SY2) corresponded to higher EC (Figure 5) and more depleted $\delta \mathrm{D}$ and $\delta^{18} \mathrm{O}$ (Figure 10c,d) was likely to be associated with groundwater influx. The fraction of groundwater contribution was calculated using stable conservative tracer EC, isotope ${ }^{222} \mathrm{Rn}, \delta \mathrm{D}$, and $\delta^{18} \mathrm{O}$ and the results suggested that the river was composed of approximately 26.02-72.00\% groundwater in April and 31.18-65.36\% in August 2019. The higher assessment was likely to be associated with minimal differences of $\delta \mathrm{D}$ and $\delta^{18} \mathrm{O}$ concentration values observed between riparian groundwater and the river.

Table 1. The mixing proportions of riparian groundwater in the dry season and wet season.

\begin{tabular}{ccccccccc}
\hline \multirow{2}{*}{ Sampling Site } & \multicolumn{4}{c}{ Dry Season } & \multicolumn{5}{c}{ Wet Season } \\
\cline { 2 - 9 } & $\mathbf{f}_{\mathbf{R n}-\mathbf{2 2 2}}$ & $\mathbf{f}_{\mathbf{O}-\mathbf{1 8}}$ & $\mathbf{f}_{\mathbf{D}}$ & $\mathbf{f}_{\mathrm{EC}}$ & $\mathbf{f}_{\mathbf{R n}-\mathbf{2 2 2}}$ & $\mathbf{f}_{\mathbf{O}-\mathbf{1 8}}$ & $\mathbf{f}_{\mathbf{D}}$ & $\mathbf{f}_{\mathrm{EC}}$ \\
\hline $\mathrm{J} 8$ & 15.37 & - & - & - & 23.20 & - & - & - \\
$\mathrm{Y} 1$ & - & - & - & - & 72.14 & 94.26 & 93.89 & 5.55 \\
$\mathrm{~S} 2$ & 6.86 & - & 4.68 & 8.37 & 30.77 & - & 32.51 & 32.33 \\
SY2 & 26.02 & 72.00 & 55.19 & 52.96 & 65.36 & 58.45 & 65.32 & 31.19 \\
\hline
\end{tabular}

$\mathrm{f}_{\mathrm{Rn}-222}, \mathrm{f}_{\mathrm{O}-18}, \mathrm{f}_{\mathrm{D}}$ and $\mathrm{f}_{\mathrm{EC}}$ indicate the mixing proportions of riparian groundwater at each site, calculated by ${ }^{222} \mathrm{Rn}$, ${ }^{18} \mathrm{O},{ }^{2} \mathrm{H}$, and EC concentrations, respectively. 
Combined with the field measurement data for river sections in November 2019, the radon mass balance model has been used to quantify the hydraulic exchange between surface water and riparian groundwater. According to the previous research, river flow and radon activity in both river and groundwater are relatively significant sensitive parameters, which cause large relative errors in this method $[13,44,64]$. Hence, in order to obtain accurate data and ensure credible results, each river cross-section was measured four times by an acoustic Doppler current profiler (ADCP, RiverSurveyor S5, Sontek company, San Diego, CA, USA). The parameters of river width $(w)$, depth (h), flow velocity $(v)$, and discharge $\left(Q_{u}\right.$ and $\left.Q_{d}\right)$ we used in the model were average values of field measurement data (Table 2). Meanwhile, the end member of ${ }^{222} \mathrm{Rn}$ activity in groundwater was considered as the mean value of four riverside wells. At the front of Zhoukou sluice, both radon activity and river discharge of the upstream site were higher than that of the downstream site. Therefore, surface water recharge groundwater plays an essential role in this river reach. By substituting the parameter into Equation (3), the calculated results show that the flux of river recharge is $3.27 \times 10^{-4} \mathrm{~m}^{3} /(\mathrm{s} \cdot \mathrm{m})$. At the front of Shenqiu sluice, both radon activity and river discharge of the upstream site were lower than that of the downstream site. Hence, the river reach was dominated by groundwater discharge. By substituting the parameter into Equation (4), the calculated results show that the flux of groundwater discharge is $3.50 \times 10^{-3} \mathrm{~m}^{3} /(\mathrm{s} \cdot \mathrm{m})$.

Table 2. The parameters of the estimated sections in the November 2019 sampling period.

\begin{tabular}{ccc}
\hline Parameters & Zhoukou Sluice (Y2) & Huaidian Sluice (SY2) \\
\hline$R n_{u}\left(\mathrm{~Bq} / \mathrm{m}^{3}\right)$ & 500 & 2118 \\
$R n_{d}\left(\mathrm{~Bq} / \mathrm{m}^{3}\right)$ & 81 & 2300 \\
$R n_{g w}\left(\mathrm{~Bq} / \mathrm{m}^{3}\right)$ & 16,856 & 23,451 \\
$Q_{u}\left(\mathrm{~m}^{3} / \mathrm{s}\right)$ & 3.26 & 11.19 \\
$Q_{d}\left(\mathrm{~m}^{3} / \mathrm{s}\right)$ & 2.11 & 13.80 \\
$L\left(\mathrm{~m}^{3}\right.$ & 60.00 & 150.00 \\
$T_{a i r}\left({ }^{\circ} \mathrm{C}\right)$ & 24.80 & 24.50 \\
$D(\mathrm{~cm} / \mathrm{s})$ & $1.32 \times 10^{-5}$ & $1.31 \times 10^{-5}$ \\
$v(\mathrm{~m} / \mathrm{s})$ & 0.01 & 0.05 \\
$h(\mathrm{~m})$ & 5.01 & 3.09 \\
$w(\mathrm{~m})$ & 102.27 & 95.2 \\
\hline
\end{tabular}

\subsection{Hydro-Chemical Process of Riparian Groundwater}

\subsubsection{Natural Factors}

Saturation index (SI) is beneficial to evaluate the equilibrium between water and minerals and illustrate the water-rock interaction [65]. The saturation state is calculated by a comparison of the activities in water samples (ion activity product) and activities at equilibrium (solubility product), which facilitates in assessing the evolution stage and identifies the controlling geochemical reactions [53]. The results indicated that the dissolution of carbonate minerals (calcite and dolomite) was the main factor controlling the chemical composition. Ionic ratios play an important role in revealing geochemical processes and controlling the changes in water quality. If the geochemical process was controlled by carbonate and gypsum, the relationship between $\left(\mathrm{Ca}^{2+}+\mathrm{Mg}^{2+}\right)$ concentrations versus $\left(\mathrm{HCO}_{3-}+\mathrm{SO}_{4}{ }^{2-}\right)$ concentrations is $1: 1$ theory [66]. Figure 12a showed that samples were on the verge of 1:1 line, which indicates $\mathrm{Ca}^{2+}$ and $\mathrm{Mg}^{2+}$ were not only mainly from carbonate but gypsum dissolution. The groundwater samples were characterized by simultaneous equilibrium with carbonate minerals. Whether the dolomite or calcite dissolution dominated the geochemical process needs to be determined. By assuming that all the $\mathrm{SO}_{4}{ }^{2-}$ is derived from gypsum dissolution in the study area, non-gypsum source calcium could be calculated by subtracting the amount of $\mathrm{Ca}^{2+}$ equivalent to the amount of $\mathrm{SO}_{4}{ }^{2-}$ from the total $\mathrm{Ca}^{2+}$ concentration and expressed as $\left(\mathrm{Ca}^{2+}\right)-\left(\mathrm{SO}_{4}{ }^{2-}\right)$ (in $\mathrm{mmol} / \mathrm{L})[67,68]$. The mole ratio of $\left(\mathrm{Ca}^{2+}-\mathrm{SO}_{4}{ }^{2-}\right) /\left(\mathrm{HCO}_{3}{ }^{-}\right)$is $1: 4$, which suggests congruent 
dissolution of dolomite, while $\left(\mathrm{Ca}^{2+}-\mathrm{SO}_{4}{ }^{2-}\right) /\left(\mathrm{HCO}_{3}{ }^{-}\right)$is $1: 2$, which indicates congruent dissolution of calcite. On the plot of $\left(\mathrm{HCO}_{3}{ }^{-}\right)$against $\left(\mathrm{Ca}^{2+}-\mathrm{SO}_{4}{ }^{2-}\right)$ (Figure $12 \mathrm{~b}$ ), samples located above the 1:4 line indicated a dolomite dominant process while, samples between the 1:4 and 1:2 line, indicated simultaneous equilibrium with carbonate minerals. Sodium is a reference element for evaluating the contribution of sea salt [69] and chemical composition in rainfall and geochemical evolution of groundwater [70]. The sodium and chloride contents in surface water and groundwater were plotted in Figure 12c. Generally, the samples plot along the 1:1 relationship line indicated $\mathrm{Na}^{+}$and $\mathrm{Cl}^{-}$were derived from similar sources (the dissolution of clastic rocks and other halite minerals) within the study area. The groundwater samples (J8-1, J8-2, J8-4, Y1-3, and SY2-1) were below and deviated 1:1 line. Meanwhile, those concentrations of $\mathrm{NO}_{3}-\mathrm{N}$ were all above $10 \mathrm{mg} / \mathrm{L}$. Hence, the anthropic origin was a possible response to extreme values of chloride. In contrast, the ratio of sodium and chloride of samples were large than 1 , and the likely origin of sodium could be from weathering Na-rich minerals (residual feldspars) [71] or from secondary processes, such as $\mathrm{Ca}(\mathrm{Mg}) / \mathrm{Na}$ ion exchange, as discussed later. The diagram $\left(\left(\mathrm{Ca}^{2+}+\mathrm{Mg}^{2+}\right)-\left(\mathrm{HCO}_{3}{ }^{-}+\mathrm{SO}_{4}{ }^{2-}\right)\right)$ versus $\left(\mathrm{Na}^{+}+\mathrm{K}^{+}-\mathrm{Cl}^{-}\right)$was employed to identify the process of cation exchange [72]. In Figure 12d, the samples were linearly related and scattered along a line of slope -1 , which presented a distribution that a decrease in $\left.\left(\mathrm{Ca}^{2+}+\mathrm{Mg}^{2+}\right)-\left(\mathrm{HCO}_{3}{ }^{-}+\mathrm{SO}_{4}{ }^{2-}\right)\right)$ was observed with an increase in $\left(\mathrm{Na}^{+}+\mathrm{K}^{+}-\mathrm{Cl}^{-}\right)$. This further validates that the cation exchange was also one of the main chemical processes that $\mathrm{Ca}^{2+}+\mathrm{Mg}^{2+}$ in the water was exchanged with previously and adsorbed on the surface of minerals in the aquifer matrix in the SRB [73].
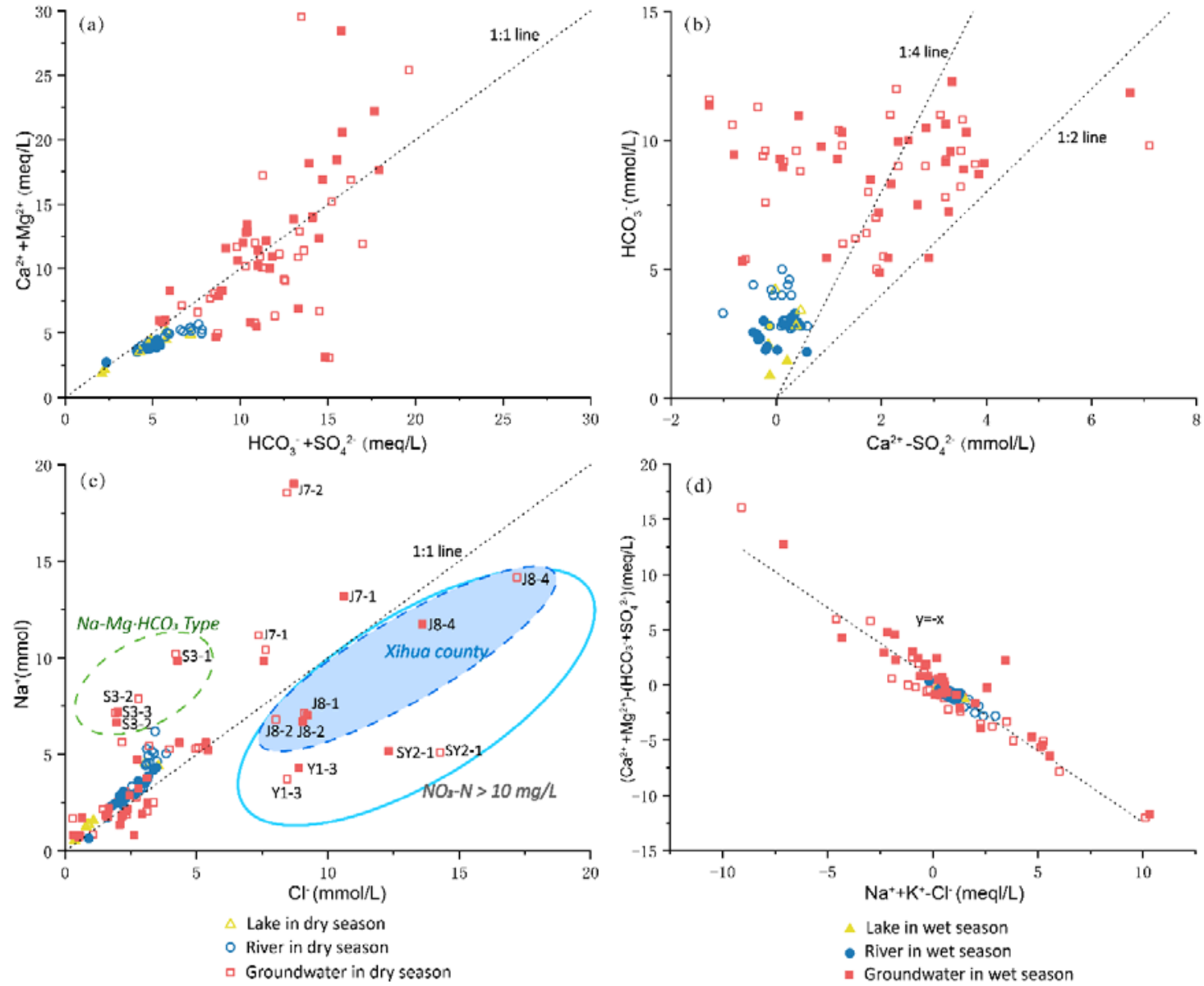

Figure 12. The diagram of the co-variation between main chemical components. (a) $\mathrm{Ca}^{2+}+\mathrm{Mg}^{2+} \mathrm{vs}$. $\mathrm{HCO}_{3}{ }^{-}+\mathrm{SO}_{4}{ }^{2-}$. (b) $\mathrm{HCO}_{3}{ }^{-}$vs. $\mathrm{Ca}^{2+}-\mathrm{SO}_{4}{ }^{2-}$. (c) $\mathrm{Na}^{+}$vs. $\mathrm{Cl}^{-}$. (d) $\left(\mathrm{Ca}^{2+}+\mathrm{Mg}^{2+}\right)-\left(\mathrm{HCO}_{3}{ }^{-}+\mathrm{SO}_{4}{ }^{2-}\right)$ vs. $\mathrm{Na}^{+}+\mathrm{K}^{+}-\mathrm{Cl}^{-}$ 


\subsubsection{Anthropogenic Factors}

The nitrogen sources in the SRB mainly contained point source pollution (including domestic sewage, industrial discharge, and livestock manure) and non-point pollution (agricultural fertilizer and atmospheric precipitation). From 2016 to 2018, the volume of ammonia nitrogen discharge produced by domestic and industrial wastewater is around 1731-9431 tons/year. The volume of nitrogen oxides emission into the atmospheric environment is about $1500-85,479$ tons/year. The amount of nitrogenous fertilizer application in the major cities is 36,029-280,631 tons/year (shown in Figure 13). For groundwater, in order to distinguish between the various sources nitrate in the basin, we used the ratio of $\mathrm{NO}_{3}{ }^{-} / \mathrm{Cl}^{-}$method. In general, low $\mathrm{Cl}^{-}$versus high ratios of $\mathrm{NO}_{3}{ }^{-} / \mathrm{Cl}^{-}$are associated with agricultural inputs while the domestic effluent and organic waste were normally characterized with high $\mathrm{Cl}^{-}$and low ratios of $\mathrm{NO}_{3}{ }^{-} / \mathrm{Cl}^{-}[72,74]$. Figure 14 showed the relationship between $\mathrm{NO}_{3}{ }^{-} / \mathrm{Cl}^{-}$ molar ratios and $\mathrm{Cl}^{-}$concentrations in water samples. Groundwater samples downstream of Jialu River showed significantly higher $\mathrm{Cl}^{-}$concentration with lower ratios of $\mathrm{NO}_{3}{ }^{-} / \mathrm{Cl}^{-}$, which suggests point pollution (domestic and industrial effluents) as the potential source of nitrate. The samples with low $\mathrm{Cl}^{-}$and high ratios of $\mathrm{NO}_{3}{ }^{-} / \mathrm{Cl}^{-}$were mainly concentrated in the Shenqiu county of Shaying River and upstream of Jialu River. Hence, non-point pollution (chemical fertilizer) was the dominant $\mathrm{NO}_{3}{ }^{-}$ in groundwater for these areas. Meanwhile, EC could also reflect the pollutant migration process. EC in groundwater showed a wide range compared with EC in surface water, and had an overall increasing trend along the flow path (Figure 5), which indicated the direction of groundwater flow in the Jialu River. It raised gradually along the Jialu River with a runoff distance from $692 \mu \mathrm{S} / \mathrm{cm}$ (T1-1) to $3680 \mu \mathrm{S} / \mathrm{cm}$ (J8-4) for the dry season and from $510 \mu \mathrm{S} / \mathrm{cm}$ to $2850 \mu \mathrm{S} / \mathrm{cm}$ for the wet season, respectively. Additionally, the water quality in groundwater of the downstream was worse than that of the upstream and the water chemistry tended to change from $\mathrm{HCO}_{3}$ type, $\mathrm{HCO}_{3}-\mathrm{SO}_{4}$ type, $\mathrm{HCO}_{3}-\mathrm{Cl}$ type, and $\mathrm{Cl}-\mathrm{HCO}_{3}$ type as $\mathrm{NO}_{3}-\mathrm{N}$ concentration increased with runoff distance. Furthermore, polluted surface water infiltration, water-rock reactions, and intensive anthropologic activities could be a possible reason for the hydro-chemical processes of groundwater in the Jialu River.
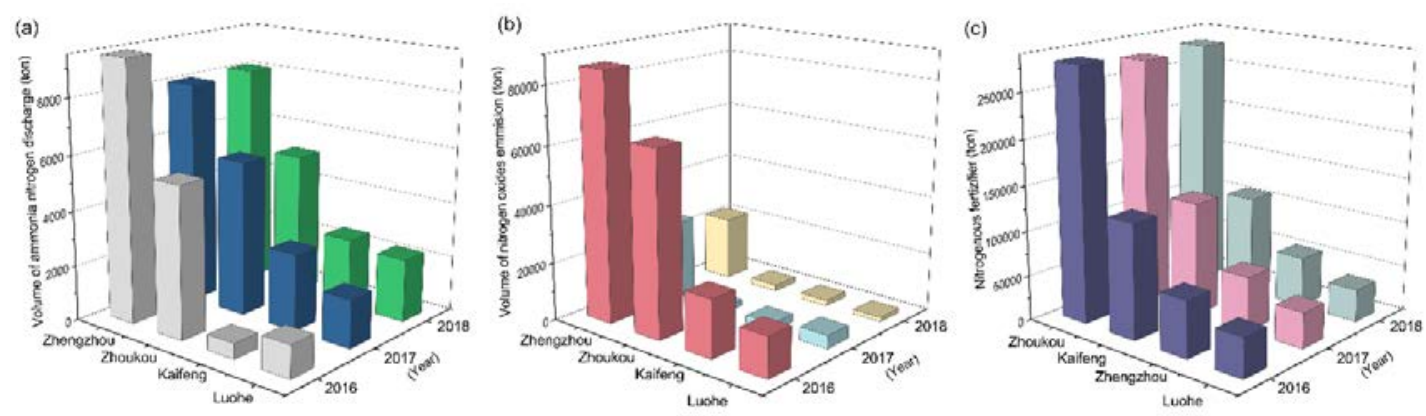

Figure 13. The nitrogen sources of pollution in the main cities of the study area. (a) Point source pollution. Non-point pollution including (b) atmospheric source and (c) agricultural fertilizer. (Data obtained from statistical yearbooks of the Henan Province. Available online: http://www.ha.stats.gov.cn/tjfw/tjcbw/tjnj/ (accessed on 1 July 2020)) 


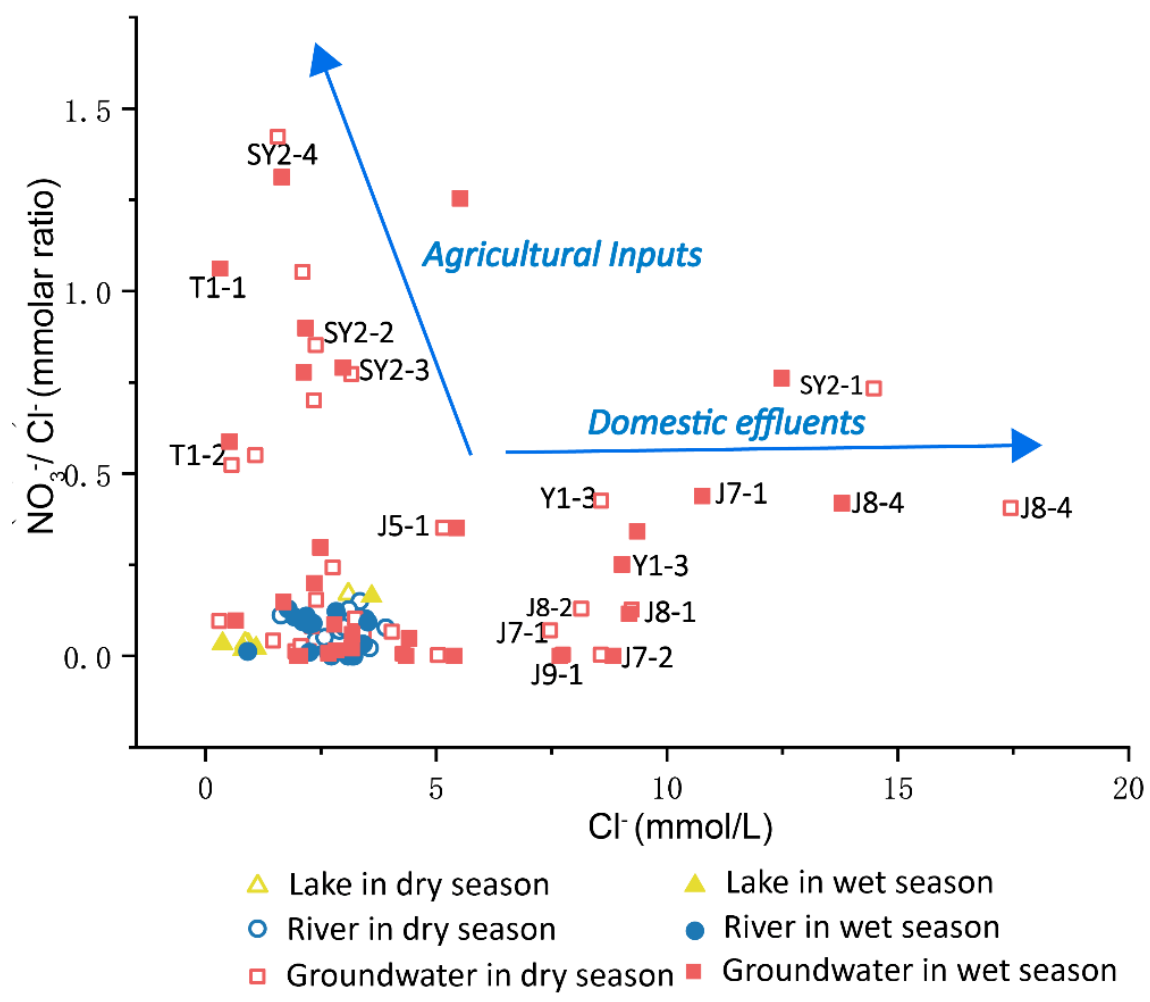

Figure 14. The relationship between $\mathrm{Cl}^{-}$and $\mathrm{NO}_{3}{ }^{-} / \mathrm{Cl}^{-}$.

\section{Conclusions}

This study has illustrated the temporal and spatial distribution of environmental tracers and their application to investigate hydrologic and hydro-chemical processes of riparian groundwater in SRB, China. It mainly provides the following findings.

1. In a combination with hydro-chemical and isotopic parameters, we identified river losing zones and gaining zones in the study area. River losing zones were along the upstream of Jialu River (between Zhengzhou and Kaifeng) and the downstream of the Ying River (Y2-Y4). River gaining zones were distributed at Xihua (J8), Zhoukou (Y1), Luohe (S2), and Shenqiu (SY2), and the fraction of groundwater was $15.37 \%, 72.14 \%, 4.58-8.37 \%$, and $26.02-72 \%$ in April while $23.23 \%, 94.26 \%, 30.77-32.51 \%$, and 31.18-65.36\% in August, respectively. The mixing extent with groundwater was greater in wet seasons than in dry seasons under the influence of sluice. Based on the results of ${ }^{222} \mathrm{Rn}$ bass balance, the flux of river recharge is $3.27 \times 10^{-4} \mathrm{~m}^{3} /(\mathrm{s} \cdot \mathrm{m})$ at $2 \mathrm{~km}$ above Zhoukou sluice, and groundwater discharge is $3.50 \times 10^{-3} \mathrm{~m}^{3} /(\mathrm{s} \cdot \mathrm{m})$ at $3 \mathrm{~km}$ above Shenqiu sluice.

2. The cation exchange, as well as the dissolution/precipitation of aquifer minerals (including calcite, dolomite, gypsum, and halite), were responsible for geochemical processes in riparian groundwater. Additionally, anthropogenic activities such as untreated sewage discharge and fertilizer usage also had striking effects on groundwater and surface water hydrochemistry.

3. Nitrogen pollution in riparian groundwater was severe $\left(\mathrm{NO}_{3}-\mathrm{N}\right.$ in $40 \%$ of the samples $(N=61)$ exceeds $10 \mathrm{mg} / \mathrm{L}$ ). Point pollution (domestic and industrial effluents) was the primary nitrate source in the downstream of Jialu River. In contrast, non-point pollution (chemical fertilizer) was the dominant nitrate source at the Shenqiu county of Shaying River. Our results suggest nitrate from riparian groundwater can deteriorate river quality at the lower reaches of the Jialu River and Shenqiu county of Shaying River through feeding river, which could be more severe during the wet seasons.

4. Furthermore, this paper could provide more helpful information for comprehensively managing water resources and effectively controlling water pollution in the SRB. Local governments could 
take effective policies, such as reduce the industrial discharge and agricultural nitrogen fertilizer in the nitrogen high-risk areas to control the industrial and agricultural contamination of the water environment.

Supplementary Materials: The following are available online at http:/www.mdpi.com/2073-4441/12/7/1939/s1. Table S1: Electric conductivity (EC), $\delta^{2} \mathrm{H}, \delta^{18} \mathrm{O}$, and ${ }^{222} \mathrm{Rn}$ data of the surface water and riparian groundwater samples for this study. Table S2: Hydro-chemical parameters. $\mathrm{NO}_{2}-\mathrm{N}, \mathrm{NH}_{3}-\mathrm{N}, \mathrm{NO}_{2}-\mathrm{N}$, TN, DOC, and CODcr data of the surface water and riparian groundwater samples for this study.

Author Contributions: Conceptualization, B.L., X.S., and L.Y. Methodology, B.L. Validation, B.L., X.S., and L.Y. Formal analysis, B.L. Investigation, B.L., L.Y., D.Y., and Y.X. Resources, B.L., L.Y., and Y.X. Writing-original draft preparation, B.L. Writing-review and editing, B.L., X.S., and L.Y. Visualization, B.L. Supervision, X.S. and L.Y. Project administration, B.L., X.S., and L.Y. Funding acquisition, X.S. and L.Y. All authors have read and agreed to the published version of the manuscript.

Funding: The National Natural Sciences Foundation of China, grant No. 41877161, funded this research.

Acknowledgments: We would like to thank the Geological Environmental Monitoring Institute of Henan Province for providing background information on the study area. We also wish to thank Xin Su, Yiran Li, Zheng Li, Bingliang Li, Jie Fan, Qiyun Xiang, and Jingyu Nuan for their assistance in the field and laboratory work.

Conflicts of Interest: The authors declare no conflict of interest.

\section{References}

1. Winter, T.C.; Harvey, J.W.; Franke, O.L.; Alley, W.M. Groundwater and Surface Water: A Single Resource; U.S. Geological Survey: Reston, VA, USA, 1998; Volume 1139.

2. Vilmin, L.; Mogollon, J.M.; Beusen, A.H.W.; Bouwman, A.F. Forms and subannual variability of nitrogen and phosphorus loading to global river networks over the 20th century. Glob. Planet. Chang. 2018, 163, 67-85. [CrossRef]

3. Pai, H.; Villamizar, S.R.; Harmon, T.C. Synoptic Sampling to Determine Distributed Groundwater-Surface Water Nitrate Loading and Removal Potential Along a Lowland River. Water Resour. Res. 2017, 53, 9479-9495. [CrossRef]

4. Zhang, P.Y.; Lee, J.; Kang, G.H.; Li, Y.Y.; Yang, D.; Pang, B.; Zhang, Y. Disparity of nitrate and nitrite in vivo in cancer villages as compared to other areas in Huai River Basin, China. Sci. Total Environ. 2017, 612, 966-974. [CrossRef]

5. Howarth, R.W.; Marino, R. Nitrogen as the limiting nutrient for eutrophication in coastal marine ecosystems: Evolving views over three decades. Limnol. Oceanogr. 2006, 51, 364-376. [CrossRef]

6. Zhang, Q.Q.; Sun, J.C.; Liu, J.T.; Huang, G.X.; Lu, C.; Zhang, Y.X. Driving mechanism and sources of groundwater nitrate contamination in the rapidly urbanized region of south China. J. Contam. Hydrol. 2015, 182, 221-230. [CrossRef] [PubMed]

7. Wachniew, P. Environmental tracers as a tool in groundwater vulnerability assessment. Acque Sotterranee 2015, 4. [CrossRef]

8. Cook, P.G. Estimating groundwater discharge to rivers from river chemistry surveys. Hydrol. Process. 2012, 27, 1-14. [CrossRef]

9. Kaandorp, V.P.; Doornenbal, P.J.; Kooi, H.; Peter Broers, H.; de Louw, P.G.B. Temperature buffering by groundwater in ecologically valuable lowland streams under current and future climate conditions. J. Hydrol. 2019, 3, 10031. [CrossRef]

10. Kurtz, W.; Franssen, H.-J.H.; Kaiser, H.P.; Vereecken, H. Joint assimilation of piezometric heads and groundwater temperatures for improved modeling of river-aquifer interactions. Water Resour. Res. 2014, 50, 1665-1688. [CrossRef]

11. Neupane, R.P.; Mehan, S.; Kumar, S. Use of geochemical tracers for estimating groundwater influxes to the Big Sioux River, eastern South Dakota, USA. Hydrogeol. J. 2017, 25, 1647-1660. [CrossRef]

12. Qin, D.J.; Zhao, Z.F.; Guo, Y.; Liu, W.C.; Haji, M.; Wang, X.H.; Xin, B.D.; Li, Y.; Yang, Y. Using hydrochemical, stable isotope, and river water recharge data to identify groundwater flow paths in a deeply buried karst system. Hydrol. Process. 2017, 31, 4297-4314. [CrossRef] 
13. Yang, J.; Yu, Z.B.; Yi, Q.; Frape, S.K.; Gong, M.; Zhang, Y.T. Evaluation of surface water and groundwater interactions in the upstream of Kui river and Yunlong lake, Xuzhou, China. J. Hydrol. 2020, 583, 124549. [CrossRef]

14. Cook, P.G.; Wood, C.; White, T.; Simmons, C.T.; Fass, T.; Brunner, P. Groundwater inflow to a shallow, poorly-mixed wetland estimated from a mass balance of radon. J. Hydrol. 2008, 354, 213-226. [CrossRef]

15. Gat, J.R. Oxygen and hydrogen isotopes in the hydrologic cycle. Annu. Rev. Earth Planet. Sci. 1996, 24, 225-262. [CrossRef]

16. Kathleen, A.M.; William, D.M.; James, M. The dynamic relationship between groundwater and the Columbia River: Using deuterium and oxygen-18 as tracers. J. Hydrol. 1992, 135, 1-12. [CrossRef]

17. Zhao, D.; Wang, G.C.; Liao, F.; Yang, N.; Jiang, W.J.; Guo, L.; Liu, C.L.; Shi, Z.M. Groundwater-surface water interactions derived by hydrochemical and isotopic (Rn-222 deuterium, oxygen-18) tracers in the Nomhon area, Qaidam Basin, NW China. J. Hydrol. 2018, 565, 650-661. [CrossRef]

18. Petermann, E.; Gibson, J.J.; Knoeller, K.; Pannier, T.; Weiss, H.; Schubert, M. Determination of groundwater discharge rates and water residence time of groundwater-fed lakes by stable isotopes of water $(\mathrm{O}-18, \mathrm{H}-2)$ and radon (Rn-222) mass balances. Hydrol. Process. 2018, 32, 805-816. [CrossRef]

19. Liao, F.; Wang, G.C.; Shi, Z.M.; Cheng, G.Q.; Kong, Q.M.; Mu, W.Q.; Guo, L. Estimation of groundwater discharge and associated chemical fluxes into Poyang Lake, China: Approaches using stable isotopes (delta D and delta O-18) and radon. Hydrogeol. J. 2018, 26, 1625-1638. [CrossRef]

20. Zhang, Y.Z.; Tang, C.Y.; Song, X.F.; Dun, Y.; Meng, W.; Zhang, Y. Concentrations, potential sources and behavior of organochlorines and phenolic endocrine-disrupting chemicals in surficial sediment of the Shaying River, eastern China. Environ. Earth Sci. 2013, 70, 2237-2247. [CrossRef]

21. Pei, M.; Li, X.Y.; Chen, F.; Liu, S.X.; Hou, C.C. The isotopomer ratios of $\mathrm{N} 2 \mathrm{O}$ in the Shaying River, the upper Huai River network, Eastern China: The significances of mechanisms and productions of $\mathrm{N} 2 \mathrm{O}$ in the heavy ammonia polluted rivers. Sci. Total Environ. 2019, 687, 1315-1326.

22. Yang, L.H.; Song, X.F.; Zhang, Y.H.; Han, D.M.; Zhang, B.; Long, D. Characterizing interactions between surface water and groundwater in the Jialu River basin using major ion chemistry and stable isotopes. Hydrol. Earth Syst. Sci. 2012, 16. [CrossRef]

23. Ma, P.; Liu, S.; Yu, Q.; Li, X.; Han, X. Sources and transformations of anthropogenic nitrogen in the highly disturbed Huai River Basin, Eastern China. Environ. Sci. Pollut. Res. 2019, 26, 11153-11169. [CrossRef]

24. He, B.N.; He, J.T.; Wang, L.; Zhang, X.W.; Bi, E.P. Effect of hydrogeological conditions and surface loads on shallow groundwater nitrate pollution in the Shaying River Basin: Based on least squares surface fitting model. Water Res. 2019, 163, 114880. [CrossRef] [PubMed]

25. Shi, W.; Xia, J.; Zhang, X. Influences of anthropogenic activities and topography on water quality in the highly regulated Huai River basin, China. Environ. Sci. Pollut. R 2016, 23, 21460-21474. [CrossRef] [PubMed]

26. Li, Y.; Wang, L.M.; Tian, H.Y.; Liu, H.P.; Wei, C.M.G. Interaction between River and Groundwater in Henan Plain of Huai River Basin. J. North China Univ. Water Resour. Electr. Power (Nat. Sci. Ed.) 2017, 38, 36-40. (In Chinese)

27. Wang, S.Q.; Tang, C.Y.; Song, X.F.; Wang, Q.X.; Zhang, Y.H.; Yuan, R.Q. The impacts of a linear wastewater reservoir on groundwater recharge and geochemical evolution in a semi-arid area of the Lake Baiyangdian watershed, North China Plain. Sci. Total Environ. 2014, 482, 325-335. [CrossRef] [PubMed]

28. Yan, Y.N.; Wang, Y.Y.; Zheng, Q.L.; Liu, L.; Zhang, J.W.; Ma, T. Assessment of Groundwater Nitrate Specific Vulnerability: A Case Study in Shaying River Basin. Environ. Sci. Technol. 2015, 38, 234-243. (In Chinese)

29. Zheng, Q.L.; Wang, Y.Y.; Yan, Y.N.; Liao, M.; Ma, T. Identification of prior control areas for nitrogen pollution blocking in shallow groundwater in Huai River Basin. J. Nanjing Univ. (Nat. Sci.) 2016, 52, 103-114. (In Chinese)

30. Chen, Z.H.; Ruan, X.H.; Shan, N. Modeling of nitrate flux between groundwater and surface water based on a coupled model in Shaying River Basin. J. Nanjing Univ. (Nat. Sci.) 2017, 53, 860-870. (In Chinese)

31. Tao, J.H.; Tao, Y.Z.; Liu, P.G. Water exchange between groundwater and main stream of Shaying River. Water Resour. Prot. 2012, 28, 37-40. (In Chinese)

32. Zuo, Q.T.; Chen, H.; Dou, M.; Zhang, Y.Y.; Li, D.F. Experimental analysis of the impact of sluice regulation on water quality in the highly polluted Huai River Basin, China. Environ. Monit. Assess 2015, 187. [CrossRef] [PubMed] 
33. Zhai, X.Y.; Xia, J.; Zhang, Y.Y. Integrated approach of hydrological and water quality dynamic simulation for anthropogenic disturbance assessment in the Huai River Basin, China. Sci. Total Environ. 2017, 598, 749-764. [CrossRef] [PubMed]

34. Zhang, D.C.; Zhang, Y.K. Application of GSFLOW to a coupled surface water and groundwater model for Shaying River Basin. Hydrogeol. Eng. Geol. 2015, 42, 1-9. (In Chinese)

35. Zuo, Q.T.; Luo, Z.L.; Shi, Y.Q.; Gan, R.; Liu, J.; Chen, H. Main parameters and physiographic characteristics of Shayinghe River Basin. Water Resour. Hydropower Eng. 2016, 47, 66-72. (In Chinese)

36. Ma, J.; He, P.; Gaohui, P. Analyzing the Drought Frequency in Shaying River Basin Using the Three-dimensional Copula Function. J. Irrig. Drain. 2017, 36, 102-107. (In Chinese)

37. Wang, X.K.; Shuan, C.S. Investigation and Evaluation of Groundwater Pollution in the Henan Plain (Huaihe Basin); Henan Insitute of Geologival Survey: Henan, China, 2013; pp. 25-40.

38. Christophersen, N.; Hooper, R.P. Multivariate analysis of stream water chemical data: The use of principal components analysis for the end-member mixing problem. Water Resour. Res. 1992, 28, 99-107. [CrossRef]

39. Clark, I.D.; Fritz, P. Environmental Isotopes in Hydrogeology Lewis; Lewis Publishers: New York, NY, USA, 1997; Volumes 12-30.

40. Kendall, C.; Mcdonnell, J.J. Isotope Tracers in Catchment Hydrology; Elsevier: Amsterdam, The Netherlands, 1998; Volumes 40-60.

41. Lee, R.W.; Hollyday, E.F. Use of radon measurements in Carters Creek, Maury County, Tennessee, to determine location and magnitude of ground-water seepage. In Field Studies of Radon in Rocks, Soils, and Water; U.S. Geological Survey: Reston, VA, USA, 1993; pp. 237-242.

42. Meredith, K.T.; Hollins, S.E.; Hughes, C.E.; Cendon, D.I.; Hankin, S.; Stone, D.J.M. Temporal variation in stable isotopes (O-18 and H-2) and major ion concentrations within the Darling River between Bourke and Wilcannia due to variable flows, saline groundwater influx and evaporation. J. Hydrol. 2009, 378, 313-324. [CrossRef]

43. Smith, A.J.; Pollock, D.W.; Palmer, D. Groundwater interaction with surface drains in the Ord River Irrigation Area, northern Australia: Investigation by multiple methods. Hydrogeol. J. 2010, 18, 1235-1252. [CrossRef]

44. Su, X.S.; Xu, W.; Yang, F.T.; Zhu, P.C. Using new mass balance methods to estimate gross surface water and groundwater exchange with naturally occurring tracer Rn-222 in data poor regions: A case study in northwest China. Hydrol. Process. 2015, 29, 979-990. [CrossRef]

45. Stellato, L.; Petrella, E.; Terrasi, F.; Belloni, P.; Belli, M.; Sansone, U.; Celico, F. Some limitations in using (222)Rn to assess river-groundwater interactions: The case of Castel di Sangro alluvial plain (central Italy). Hydrogeol. J. 2008, 16, 701-712. [CrossRef]

46. Peng, T.H.; Takahashi, T.; Broecker, W.S. Surface Radon Measurements in North Pacific Ocean Station PAPA. J. Geophys. Res. 1974, 79, 1772-1780. [CrossRef]

47. Ellins, K.K.; Romanmas, A.; Lee, R. Using Rn-sss to examine groundwaters surface discharge interaction in the rio-grande-de-manati, pueto-rico. J. Hydrol. 1990, 115, 319-341. [CrossRef]

48. Sarikhani, R.; Dehnavi, A.G.; Ahmadnejad, Z.; Kalantari, N. Hydrochemical characteristics and groundwater quality assessment in Bushehr Province, SW Iran. Environ. Earth Sci. 2015, 74, 6265-6281. [CrossRef]

49. Chung, S.Y.; Venkatramanan, S.; Park, N.; Rajesh, R.; Ramkumar, T.; Kim, B.W. An assessment of selected hydrochemical parameter trend of the Nakdong River water in South Korea, using time series analyses and PCA. Environ. Monit. Assess 2015, 187. [CrossRef]

50. Bouzourra, H.; Bouhlila, R.; Elango, L.; Slama, F.; Ouslati, N. Characterization of mechanisms and processes of groundwater salinization in irrigated coastal area using statistics, GIS, and hydrogeochemical investigations. Environ. Sci. Pollut. Res. 2015, 22, 2643-2660. [CrossRef]

51. Critelli, T.; Vespasiano, G.; Apollaro, C.; Muto, F.; Marini, L.; De Rosa, R. Hydrogeochemical study of an ophiolitic aquifer: A case study of Lago (Southern Italy, Calabria). Environ. Earth Sci. 2015, 74, 533-543. [CrossRef]

52. Apollaro, C.; Fuoco, I.; Brozzo, G.; De Rosa, R. Release and fate of Cr (VI) in the ophiolitic aquifers of Italy: The role of $\mathrm{Fe}$ (III) as a potential oxidant of $\mathrm{Cr}$ (III) supported by reaction path modelling. Sci. Total Environ. 2019, 660, 1459-1471. [CrossRef] [PubMed]

53. Parkhurst, D.L.; Appelo, C. User's guide to PHREEQC (Version 2): A computer program for speciation, batch-reaction, one-dimensional transport, and inverse geochemical calculations. Water Resour. Investig. Rep. $1999,99,312$. 
54. WHO. Guidelines for Drinking-Water Quality, 4th ed.; WHO: Geneva, Switzerland, 2011.

55. Craig, H. Isotopic variations in meteoric waters. Science 1961, 133, 1702-1703. [CrossRef] [PubMed]

56. Longinelli, A.; Selmo, E. Isotopic composition of precipitation in Italy: A first overall map. J. Hydrol. 2003, $270,75-88$

57. Vespasiano, G.; Apollaro, C.; De Rosa, R.; Muto, F.; Larosa, S.; Fiebig, J.; Mulch, A.; Marini, L. The Small Spring Method (SSM) for the definition of stable isotope-elevation relationships in Northern Calabria (Southern Italy). Appl. Geochem. 2015, 63, 333-346. [CrossRef]

58. Wang, L.H.; Dong, Y.H.; Xu, Z.F. A synthesis of hydrochemistry with an integrated conceptual model for groundwater in the Hexi Corridor, northwestern China. J. Asian Earth Sci. 2017, 146, 20-29. [CrossRef]

59. Aji, K.; Tang, C.; Song, X.; Kondoh, A.; Sakura, Y.; Yu, J.; Kaneko, S. Characteristics of chemistry and stable isotopes in groundwater of Chaobai and Yongding River basin, North China Plain. Hydrol. Process. 2008, 22, 63-72. [CrossRef]

60. Li, F.D.; Pan, G.Y.; Tang, C.Y.; Zhang, Q.Y.; Yu, J.G. Recharge source and hydrogeochemical evolution of shallow groundwater in a complex alluvial fan system, southwest of North China Plain. Environ. Geol. 2008, 55, 1109-1122. [CrossRef]

61. WMO/IAEA. Global Network of Isotopes in Precipitation. The GNIP Database. Available online: http: //nds121.Iaea.org/wiser/index.php (accessed on 1 September 2010).

62. Kong, Y.L.; Pang, Z.H.; Froehlich, K. Quantifying recycled moisture fraction in precipitation of an arid region using deuterium excess. Tellus B 2013, 65. [CrossRef]

63. Zheng, Y.H.; Zhang, Y.K.; Liang, X.Y. A Study of Groundwater Flow and Water Quality Characteristics in the Riparian Zone of Jialu River near Zhongmu. Geol. J. China Univ. 2015, 21, 234-242. (In Chinese)

64. Yi, P.; Luo, H.; Chen, L.; Yu, Z.B.; Jin, H.J.; Chen, X.B.; Wan, C.W.; Aldahan, A.; Zheng, M.J.; Hu, Q.F. Evaluation of groundwater discharge into surface water by using Radon-222 in the Source Area of the Yellow River, Qinghai-Tibet Plateau. J. Environ. Radioact. 2018, 192, 257-266. [CrossRef] [PubMed]

65. Moore, P.J.; Martin, J.B.; Screaton, E.J.; Neuhoff, P.S. Conduit enlargement in an eogenetic karst aquifer. J. Hydrol. 2010, 393, 143-155. [CrossRef]

66. Yu, J.C.; Mo, X.X.; Yu, X.H.; Dong, G.C.; Fu, Q.; Xing, F.C. Geochemical characteristics and petrogenesis of Permian basaltic rocks in Keping area, Western Tarim basin: A record of plume-lithosphere interaction. J. Earth Sci. 2012, 23, 442-454. [CrossRef]

67. Wang, Y.X.; Guo, Q.H.; Su, C.L.; Ma, T. Strontium isotope characterization and major ion geochemistry of karst water flow, Shentou, northern China. J. Hydrol. 2006, 328, 592-603. [CrossRef]

68. Zang, H.F.; Zheng, X.Q.; Jia, Z.X.; Chen, J.F.; Qin, Z.D. The impact of hydrogeochemical processes on karst groundwater quality in arid and semiarid area: A case study in the Liulin spring area, north China. Arab. J. Geosci. 2015, 8, 6507-6519. [CrossRef]

69. Negrel, P.; Petelet-Giraud, E. Strontium isotopes as tracers of groundwater-induced floods: The Somme case study (France). J. Hydrol. 2005, 305, 99-119. [CrossRef]

70. Alvarado, J.A.C.; Paces, T.; Purtschert, R. Dating groundwater in the Bohemian Cretaceous Basin: Understanding tracer variations in the subsurface. Appl. Geochem. 2013, 29, 189-198. [CrossRef]

71. Paces, T. Steady-state kinetics and equilibrium between ground-water and granitic rock. Geochim. Cosmochim. Acta 1973, 37, 2641-2663. [CrossRef]

72. Liu, F.; Song, X.F.; Yang, L.H.; Han, D.M.; Zhang, Y.H.; Ma, Y.; Bu, H.M. The role of anthropogenic and natural factors in shaping the geochemical evolution of groundwater in the Subei Lake basin, Ordos energy base, Northwestern China. Sci. Total Environ. 2015, 538, 327-340. [CrossRef] [PubMed]

73. Edmunds, W.M.; Guendouz, A.H.; Mamou, A.; Moulla, A.; Shand, P.; Zouari, K. Groundwater evolution in the Continental Intercalaire aquifer of southern Algeria and Tunisia: Trace element and isotopic indicators. Appl. Geochem. 2003, 18, 805-822. [CrossRef]

74. Anornu, G.; Gibrilla, A.; Adomako, D. Tracking nitrate sources in groundwater and associated health risk for rural communities in the White Volta River basin of Ghana using isotopic approach (delta N-15, delta O-18-NO3 and H-3). Sci. Total Environ. 2017, 603, 687-698. [CrossRef]

(C) 2020 by the authors. Licensee MDPI, Basel, Switzerland. This article is an open access article distributed under the terms and conditions of the Creative Commons Attribution (CC BY) license (http://creativecommons.org/licenses/by/4.0/). 